\title{
Yüsrî ve Esmâ-yı Libâs kasidesi
}

\section{Zehra ÖZTÜRK171}

APA: Öztürk, Z. (2020). Yüsrî ve Esmâ-yı Libâs kasidesi. RumeliDE Dil ve Edebiyat Araştırmaları Dergisi, (20), 377-401. DOI: 10.29000/rumelide.791779.

\section{$\ddot{\mathbf{O} z}$}

Yüsrî, XVIII. yüzyılda yaşamış bir şairdir. Yüsrî’nin hayatı hakkında biyografik kaynaklarda herhangi bir bilgi yoktur. Şairin, Divan'ında bulunan şiirlerinden yola çıkılarak XVIII. yüzyılda yaşadığı anlaşılır. Şiirlerinde, Girit'e bağlı Resmo'dan bahsetmesi sebebiyle şairin orada yaşadığı ya da bir süre orada bulunduğu düşünülebilir. Esmâ-yı Libâs kasidesi Yüsrî̀nin Divan'ında bulunan beş kasideden biridir. Divandaki dördüncü kaside olan bu manzume "Esmâ-yı Libâsı Müştemil Kaside” başlığını taşır. Yüsrî, bu şiiri giyim kuşam terimleriyle yazmıştır. Klasik kaside muhtevası dışında yazılmış olan eserde, şairin yaşadığı dönemde kullanılan kıyafet ve kumaş adlarına yer verilir. Yüsrî, eserinde kıyafet ve kumaş adlarını tevriye sanatından faydalanarak çeşitli anlamlara gelecek şekilde kullanır. Şair, Esmâ-yı Libas kasidesinde; dest-mâl, arak-çîn, fes, sûfî, tâc, bend, hilâlî, anterî, kapama, kutnî, sâde, taraklı şal, alaca, kabâ gibi günümüzde anlamları bilinen kıyafetlerin yanında, kaynaklarda hakkında bilgi bulunmayan gül-i âh, köse, cûdî, şeşkezî, mîrzâyi, burûc gibi kıyafet ve kumaş adlarına da yer verir. Yüsrî̀nin giyim sahasına ait terimlerle yazdığı bu manzume devrin sosyal hayatına ve geleneklerine de ışık tutar. Esmâ-yı Libâs kasidesi, giyim kuşam literatürüne katkı sağlaması ve XVIII. yüzyılın sosyal hayatına dair bilgiler vermesi bakımından önemlidir. Bu makalede; şairin hayatı, eserleri ve Esmâ-yı Libâs kasidesi ile ilgili bilgiler verilecek ve Esmâ-yı Libâs kasidesinin nüsha karşılaştırmalı metnine yer verilecektir.

Anahtar kelimeler: Yüsrî, Esmâ-yı Libâs, giyim, XVIII. yüzyıl

\section{Yusri and his poem "Esma-i Libas kasidesi”}

\begin{abstract}
Yusri is a poet who lived in the $18^{\text {th }}$ century. There is no information in the biographical sources about Yusri's life. Based on the poems in the Divan of the poet, it is understood that he lived in the $18^{\text {th }}$ century. In his poems, it may be thought that the poet lived there or had been there for a while, because he talked about Resmo connected to Crete. Esma-yı Libas is one of the five odes in the Divan of Yusri. This verse, which is the fourth ode in the Divan, bears the title of "Esma-i Libası Mustemil Kaside" The work, which is written outside the content of the classical ode, contains the names of clothes and fabrics used during the poet's lifetime. üsrî uses the names of clothes and fabrics in his work, making use of the art of tevriye, in a way that means various meanings. The poet includes clothes known as the dest-mal, arak-chin, fes, sufi, tac, afitab, bend, hilali, anteri, kapama, kutni, sade, taraklı şal, alaca, kaba in Esma-i Libas, which are known today. In poetry, there are clothing names that do not have information about sources such as gul-i ah, cudi, kose, seshkezi, mirzayi, buruc. This verse written by Yusri in terms of the clothing field sheds light on the social life and traditions of the period. Esma-i Libas poetry is important in terms of contributing to the clothing
\end{abstract}

171 Arş. Gör., Bursa Uludağ Üniversitesi, Fen Edebiyat Fakültesi, Türk Dili ve Edebiyatı Bölümü (Bursa, Türkiye), zehraozturk@uludag.edu.tr, ORCID ID: oooo-0002-4686-3958 [Makale kayt tarihi: 21.05.2020-kabul tarihi: 20.09.2020; DOI: 10.29000/rumelide.791779] 
literature and providing information about the social life of the $18^{\text {th }}$ century. In this article; after giving information about the poet's life, his works, the content of Esma-i Libas, the comparative text of Esma-i Libas will be included.

Keywords: Yusri, Esma-yı Libas, clothing, $18^{\text {th }}$ century

\section{Giriş}

Divan edebiyatı, yaklaşı altı yüz yıllık uzun bir süreci kapsar. Bu dönemde hem manzum hem de mensur çok sayıda eser kaleme alınır. Özellikle manzum tarzda yazılmış eserler; Divan edebiyatının araştırmacılar tarafından günlük hayattan kopuk ve toplumsal koşulları yansıtmayan bir edebiyat olduğu gerekçesiyle eleştirilmesine neden olur. Agâh Sırrı Levend bu durumu "Divan edebiyatı içtimai bir edebiyat değildir... Divan edebiyatı serde yetiştirilmiş çiçekler gibi, hemen soluverecek zannolunur; hakiki hayattan o kadar nasibi azdır." (Levend, 2015: 646-647) sözleriyle ifade eder. Ancak sözlerini "Fakat yaşadığı devr itibariyle yine onun sadık bir aynası olduğu da muhakkaktır." (Levend, 2015: 647) şeklinde tamamlar. Levend, Divan edebiyatını hayattan kopuk olmakla itham etse de onun devrinin özelliklerini yansıttığına da vurgu yapar. Levend'in Divan edebiyatının kaynakları arasında "tarih ve esatir, batıl ve hakiki bilgiler, hayat, bezm ü rezm, hadiseler, âdet ve ahlâk" başlıklarına yer vermesi de Divan edebiyatının toplumsal olaylarla ve sosyal hayatla iç içe olduğunu gösterir. (Levend, 2015: 15-16) Muhammed Nur Doğan, Divan edebiyatının toplumla iç içe oluşunu "Her toplumun edebiyatı gibi bizim öz edebiyatımız da kendini doğuran, ona vücut verip rengini, tarzını, dünya görüşünü oluşturan kaynaklara sıkı sıkıya bağlıdır ve bir anlamda kültürümüz ve değerler sistemimizin estetik planda yansımasıdır.” (Doğan, 2011: 48) şeklinde ifade eder. Yapılan çalışmalar, Divan edebiyatının sosyal hayatı kaynak olarak benimsediğini ve toplum hayatına ayna tuttuğunu gösterir mahiyettedir. ${ }^{172}$

Yüsrî’nin Divan'ında bulunan “Esmâ-yı Libâsı Müştemil Kaside” başlıklı kaside de sosyal hayatın Divan şiirine yansımasının bir örneğidir. Yüsrî, 57 beyitten oluşan kasidesinde yaşadı̆̆ dönemde kullanılan 67 kıyafet ve kumaş adına yer verir. Şair, şiirinde kıyafet adlarını tevriyeli biçimde kullanır ve devrin gelenek ve göreneklerine de işık tutar.

Yüsrî Divanı, 2001 yılında Aslıhan Yıldız Acar ve 2016 yllında Mustafa Atak tarafından olmak üzere iki kez yüksek lisans tezi olarak hazırlanmıştır. İlyas Kayaokay, 2018 yılında hazırladığı "Divan Şiirinde Elbise Terimleriyle Yazılmış Manzumeler” başlıklı makalesinde Yüsrînin Esmâ-yı Libâs kasidesine de yer verir. Yapılan çalışmalarda bazı kıyafet adlarının eksik olması, çalışmaya dâhil ettiğimiz yeni nüshalar ve bazı farklı okumalar dolayısıyla Esmâ-yı Libâs kasidesinin edebiyat ve kültür tarihimize katkı yapacağı düşünülerek konunun bu makalede ele alınmasına karar verilmiştir.

\section{Yüsrî’nin hayatı ve eserleri}

Yüsrî Divanı ile ilgili hazırlanan iki tezde de şairin hayatıyla ilgili bilgi bulunmadığı belirtilir. İki çalışmada da Yüsrî ile aynı mahlası kullanan dört şair hakkında kısaca bilgi verilir. (Acar, 2002: XVI) (Atak, 2016: 16-17) Hem Acar hem de Atak Tezkirelere Göre Divan Edebiyat İsimler Sözlüğ̈̈’nü kaynak alarak Yüsrî mahlasını kullanan Ahmed adlı iki şaire yer verir. Ancak Tezkirelere Göre Divan Edebiyatı İsimler Sözlüğü incelendiğinde Yüsrî mahlaslı Ahmed adlı şairin Safâyî ve Sâlim tezkireleri kaynak alınarak iki farklı kişi olarak kaydedildiği görülür. (İpekten vd., 1988: 539-540) Bunun muhtemel sebebi

\footnotetext{
172 Ayrıntılı bilgi için bknz. Fatma Meliha Şen, “Eski Türk Edebiyatında Sosyal Hayat Çalışmaları”, Türkiye Araştırmaları Literatür Dergisi, cilt 5, sayı 9, 2007, s. 467-506
} 
ise şairin ölüm tarihinin Safâyî Tezkiresỉnde 1105/1694 yerine yanlışlıkla 1135/1722-1723 olarak kaydedilmiş olmasıdır. İsmail Hakkı Aksoyak, Türk Edebiyatı İsimler Sözlüğü’nde Safâyî ve Sâlim'in tezkirelerindeki Yüsrî Ahmed’i aynı kişi kabul ederek Yüsrî Ahmed maddesini oluşturmuş ve Safâyî Tezkiresi’nde ölüm tarihinin yanlış yazıldığını belirtmiştir. (Aksoyak, 2014) Bu bilgiler göz önüne alınarak kaynaklar incelendiğinde çalışmamıza konu olan Yüsrî dışında bu mahlası kullanan şairler şunlardır:

Yüsrî Ahmed: H. 1046/M. 1636-1637 senesinde doğdu. Çeşitli medreselerde görev yaptıktan sonra H.1105/M.1694 yılında Şam kadısı olarak atandı. Aynı yıl Zilkade ayında Şam'da vefat etti. (İnce, 2005: 708-709) Safâyî Tezkiresìnde ve Osmanl Müellifleri’nde İstanbul'da doğduğu bilgisi de yer alır. (Çapan, 2005: 736) (Saraç, 2016: 934) Safâyî Tezkiresỉnde ölüm tarihi yanlışlıkla H. 1135/M.1722-1723 olarak kaydedilmiştir. Divan'ı, Münşeat'ı ve Sadru'ş-Şerîa Ta'likkât'ı vardır. (Aksoyak, 2014) Osmanh Müellifleri’nde şairin Mükeffiyat-ı Hamse-Esmârü'l-Eshâr adlı bir risalesi ve manzum bir nasihatnâmesi olduğundan bahsedilir. (Saraç, 2016: 934) İlim ve fazilet sahibi, inşada usta ve üç dilde şiir söylemeye muktedir bir şairdir. (Özcan, 1989: 86)

Yüsrî Abdurrahman Efendi: Kebîrî-zâde Efendi adıyla tanınır. H. 1077/M. 1666-1667 yllında doğmuştur. Ordu kadılığıyla tanınmış Kebîrî-zâde Mustafa Efendi’nin oğludur. Kendisi de babası gibi kadıdır. Halep, Edirne ve Mekke'de kadılık görevlerinde bulunur. Şair, Sâlim Tezkiresìnin yazıldığı yllarda (H. 1099-1034/M. 1688-1722) hayattadır. (İnce, 2005: 707)

Yüsrî Hızır Efendi: Manisalıdır. Satranç oyununda ustadır. İshak Çelebi ile padişahın huzurunda satranç oynamıştır. (İnce, 2005: 708) Satrancî Hızır Efendi adıyla meşhurdur. (Kurnaz, 2001: 1221)

Yüsrî: Safâyî Tezkiresi’nde şairin namı boş bırakılmış ve Diyarbakır'dan zuhur ettiği söylenmiştir. (Çapan, 2005: 739) Tuhfe-i Nâilî’de ölüm tarihi H. 1070/M. 1659 olarak kaydedilmiştir. (Kurnaz, 2001: 1220)

Kaynaklar incelendiğinde tezkirelerde bulunan şiir örnekleri ile ilgili de karışıklık olduğu görülür. Safâyî Tezkiresi’nde Diyarbakırlı Yüsrî̀ye ait olduğu söylenen gazel Yüsrînnin Divan'ındaki 120 numaralı gazelidir.

Nigāh-1 ġamze-dārı̀ dāg̀-1 dilde tīşe-zenlikde

Akıtdı cūy-1 hūnum menzil aldı kūh-kenlikde [Çapan, 2005: 739] [Atak, 2016: 179]

Osmanl Müellifleri’nde Yüsrî Ahmed Efendi (İstanbulî) başlı̆̆ında "Ahmed Efendi’nin ebyatındandır." diye sunulan üç beyit incelediğinde kelime düzeyinde farklılıklar olsa da bu beyitlerin Esmâ-yı Libâs şairi Yüsrî̀ye ait olduğu görülür.

Kays'a Leylâ idi Mevlâ talebinden rehber

Sen de tut semt-i mecâzı deliden uslu haber [Saraç, 2016: 934] [Atak, 2016: 125]

Derdimiz cânâna söylenmiş devâ söylenmemiş

Mâcerâ söylenmiş ammâ müdde'â söylenmemiş [Saraç, 2016: 934] [Atak, 2016: 149] 
Düzgün de olsa dinletemez bezm-i yârda

Sâz-1 niyâzı ehl-i hevâ hep bozuk çalar [Saraç, 2016: 934] [Atak, 2016: 128]

Çalışmamızın konusu olan Yüsrî ile ilgili yalnızca iki kaynakta bilgi bulunmaktadır. Tuhfe-i Nâilî’de şairin hayatı hakkında tezkirelerde bir kayıt bulunmadığı belirtilir. Divan'ında yer alan tarihler sebebiyle şairin H. 1120/M. 1717 tarihinde hayatta olduğunun anlaşıldığı söylenir. Şairin Divan'ının biri Millet Kütüphanesi’nde, ikisi İstanbul Üniversitesi Kütüphanesi’nde bulunan üç nüshasının bilgileri de yer alır. (Kurnaz, 2001: 1221) Türk Dili ve Edebiyat Ansiklopedisi Devirler, İsimler, Eserler, Terimler adlı çalışmada Yüsrî ile ilgili XVIII. yüzyılda yaşamış bir divan şairi olduğu ve hakkında bilgi bulunmadığı söylenir. Millet Kütüphanesi'nde ve İstanbul Üniversitesi Kütüphanesi'nde bulunan Divan'inda yer alan 1717 tarihinden bu asırda yaşadığı ve Girit’ten epeyce bahsedilmesine dayanarak buralı olabileceği ifade edilir. (1998: 628) Divan’ı üzerine yapılan iki çalışmada da şairin hayatı hakkında bilgi bulunmadığı belirtilir. (Acar, 2002: XIV) (Atak, 2016: 17) Aslıhan Yıldız Acar'ın hazırladığı çalışmada şairin adı yer almaz. Mustafa Atak tarafından hazırlanan yüksek lisans tezi Yüsrî Ahmed Nazif Dede Divanı adını taşır. Bunun sebebi ise kaynaklarda herhangi bir bilgi bulunmamasına rağmen http://www.yazmalar.gov.tr/ adresinde şairin Divan'ının Yüsrî Ahmed Nazif Dede adıyla kaydedilmesidir.

Her iki çalışmada da Yüsrr̂̀nin şiirlerinden yola çıkılarak şairin hayatıyla ilgili bazı bilgilere ulaşılmıştır. Aşağıdaki beyitler sırasıyla Girit kasabalarından Resmo'daki Ahmed Paşa Camii imamı Kurra Efendi’nin katledilişi ve yine Resmo'da katledilmiş olan vezir Muhammed Ağa için yazılmıştır.

Çı̣̂dı üçler didiler ḳatline Yüsrī tārīh

Oldı sermed şühedā zümresine Ḥacı imām

Geçüp serden mis̄āl-i cüsse-i tārīh-i pür-daġım

Muhammed kethüdaya menzil-i evvel na 'īm oldı
H. 1136/M. 1723

\section{H. 1129/M. 1717}

Bu iki beyit şairin XVIII. yüzyılda yaşadığını ve 1723 tarihinde hayatta olduğunu göstermektedir. Yüsrînnin, Resmo'da yaşayan Köprülü-zâde Es'ad Paşa'ya sunduğu, Divan'ın üçüncü kasidesi olan "kerem" redifli kaside ve çalışmamızın konusu olan Esmâ-yı Libâs kasidesindeki

Köprüli-zāde yegāne güher Es``ad Paşa

Lābis-i çargabab-1 şāh-1 mülk-i ‘irfan

beytine dayanarak Yüsrî’nin Resmo'da yaşadığı ya da bir süre burada kaldığı söylenebilir. Şairin, Es'ad Paşa'ya kaside sunması ve ondan övgüyle söz etmesi de Es'ad Paşa'nın şairin hayatında önemli bir yeri olduğunu göstermektedir. (Acar, 2020: XIV-XV) (Atak, 2016: 17-19)

Kaynaklara göre şairin tespit edilebilen tek eseri Divan'ıdır. www.yazmalar.gov.tr adresinde Ahmed Nazif Dede adına kayıtlı Risâle-i Burûc-ı Fünûn ve Risâle-i Manzûm adlı iki eser daha bulunmaktadır. Astroloji ile ilgili bir eser olan Risâle-i Burûc-ı Fünûn'un tek nüshası Vatikan Kütüphanesi Türkçe Yazmaları bölümündedir. Mustafa Atak, Vatikan'a gittiğini ancak kütüphanenin izin vermemesi nedeniyle eseri göremediğini belirtir. (Atak, 2016: 20) Risâle-i Manzûm ise Milli Kütüphane'de o6 Mil Yz A 4267/4 numarasıyla kayıtlıdır. Eser, manzum nasihat-nâme türündedir. Sayfalardan birinin altında "İşbu risāle-i manzūm Naẓif Efendi’nüy” notu vardır. Osmanlı Müellifleri’nde Yüsrî Ahmed Efendi'ye ait olduğu söylenen manzum nasihat-nâme Yüsrî Ahmed Nazif Dede’ye ait olabilir ancak net bir hüküm vermek mümkün değildir. 
Yüsrî Ahmed Nazîf Dede Divanı'nın tespit edilebilen dokuz nüshası vardır. Nüshalar, İstanbul Üniversitesi Kütüphanesi No. T. 2912, İstanbul Üniversitesi Kütüphanesi No. 2841, Millet Kütüphanesi Ali Emîrî Efendi Manzum Eserler No. 515, Milli Kütüphane o6 Yz A 5357, Topkapı Sarayı Türkçe Yazmaları No. H. 963, Topkapı Sarayı Türkçe Yazmaları No. H. 963, Topkapı Sarayı Türkçe Yazmaları No. H. 966, Yapı Kredi Sermet Çifter Araştırma Kütüphanesi Türkçe Yazmaları No. 688/1, Yapı Kredi Sermet Çifter Araştırma Kütüphanesi Türkçe Yazmaları No. 1016, Oxford- İngiltere Bodleian Kütüphanesi Türkçe Yazmaları No. MS Turk. d. 48 şeklinde kaydedilmiştir. Bunlardan Millet Kütüphanesi’nde Ali Emîrî Manzum Eserler Bölümü’nde bulunan nüsha Yüsrî ve Yüsrî Ahmed Nazif Dede adına iki kere kaydedilmiştir.

Aslıhan Yıldız Acar, Divan metnini İstanbul Üniversitesi Kütüphanesi No. T.2912, İstanbul Üniversitesi Kütüphanesi No. 2841 ve Millet Kütüphanesi Ali Emîrî Efendi Manzum Eserler No. 515 nüshalarını kullanarak oluşturmuştur. Mustafa Atak ise ulaşabildiği İstanbul Üniversitesi Kütüphanesi No. T.2912, İstanbul Üniversitesi Kütüphanesi No. 2841, Milli Kütüphane o6 Yz A 5357, Millet Kütüphanesi Ali Emîrî Efendi Manzum Eserler No. 515, Topkapı Sarayı Türkçe Yazmaları No. H. 963, Topkapı Sarayı Türkçe Yazmaları No. H. 963, Topkapı Sarayı Türkçe Yazmaları No. H. 966 nüshalarından beşini kullanmış, Topkapı Sarayında bulunan H. 963 numaralı nüshayı imla yanlışlarının çokluğu sebebiyle metne dâhil etmemiştir. Biz bu nüshalardan sekiz tanesine ulaştık. İngiltere'de Bodleian Kütüphanesi'nde bulunan nüsha kütüphanenin yazma eserleri dijitalleştirmemesi sebebiyle elde edilemedi. Yapılan divan neşri çalışmalarından farklı okumalar olduğu için Esmâ-yı Libâs kasidesinin metnini yeniden oluşturmayı uygun gördük. Metni oluştururken bu nüshalardan beşinden faydalandık. Milli Kütüphane 06 Yz A 5357 ve Yapı Kredi Sermet Çifter Araştırma Kütüphanesi Türkçe Yazmaları No. 1016 nüshalarında Esmâ-yı Libâs kasidesi yer almadığı için, Topkapı Sarayı Türkçe Yazmaları No. H. 963 nüshası ise imla yanlışlarının çokluğu sebebiyle çalışmaya dâhil edilmedi. Kaside metni oluşturulurken

İstanbul Üniversitesi Kütüphanesi No. T.2912 (İ1)

İstanbul Üniversitesi Kütüphanesi No. 2841 (İ2)

Millet Kütüphanesi Ali Emîrî Efendi Manzum Eserler No. 515 (M1)

Topkapı Sarayı Türkçe Yazmaları No. H. 966 (T1)

Yapı Kredi Sermet Çifter Araştırma Kütüphanesi Türkçe Yazmaları No. 688/1 (Y1) nüshalarından faydalanılmıştır. M1 dışındaki tüm nüshalarda kıyafet adlarının üstü kırmızı mürekkeple çizilerek belirtilmiştir. Esmâ-yı Libâs kasidesi, Milli Kütüphane'de o6 Mil Yz FB 533/1 numaralı Mecmû́a-i Eş‘âr'ın 4ob sayfasında da kayıtlıdır. Bu mecmuada kıyafet adları kırmızı mürekkeple yazılmıştır. Mecmuada bulunan metin, neşre dâhil edilmese de kıyafet adlarının belirlenmesinde bu metinden de faydalanılmıştır. Metinlerin her birinde bulunan kıyafet sayısı farklıdır. Bu nedenle Esmâ-yı Libâs'ın metni oluşturulurken yazma eserlerin hepsi göz önünde bulundurularak kıyafet adları koyu şekilde yazılmıştır.

\section{Esmâ-yı Libâs kasidesi}

Yüsrî Divanı'nda 5 kaside, 133 gazel, 7 tarih, 5 kut'a ve 34 müfred vardır. (Atak, 2016: 20-23) Divandaki ilk kaside tevhid, ikinci kaside ise "Esmâ-yı Kütübi Müştemil Na' t-1 Şerîf” başlı̆̆ını taşıyan bir na ‘ttır. Yüsrî bu kasidede önceki yüzyıllarda yazılmış eserlerin adlarına ve özelliklerine yer verir. Bu şiir, şairin 
eğitimli ve bilgili olduğunun göstergesi kabul edilebilir. Üçüncü kaside Köprülü-zâde Es‘ad Paşa için yazılmış kerem redifli bir kasidedir. Beşinci kaside ise şairin kendi ifadesiyle "duyulmamış atasözleri”ni içerir. Kasideler incelendiğinde Yüsrî’nin orijinallik kaygısı taşıyan bir şair olduğu görülür. Divan'la ilgili yapılan çalışmalarda Yüsrî’nin Arapça ve Farsça'yı iyi bildiği, bilgili bir şair olmasının yanında halk kültüründen de haberdar olduğu söylenir. (Acar, 2002: XXI) Özellikle kasidelerinde süslü, ağır bir dil kullanan şairin Arapça ve Farsçaya şiirlerinde yoğun olarak yer verdiği görülür. Yüsrî, şair olarak kendisini beğenmekte ve şiirlerinin anlaşılması konusunda sıkıntı yaşanmayacağını düşünmektedir.

Hezār ezber oḳur rāz-1 derūn-1 ġonceyi Yüsrī

Ne denlü olsa da mānende-i țūmar-1 piçe-a-pīç

[Ey Yüsrî! Bülbül, ne denli kıvrılmış tomara benzese de goncanın derinindeki sırrı ezbere okur.] Beyti şairin hem kendisini şöhretli bulduğunu hem de şiirlerinin anlaşılır olduğunu düşündügünü gösterir. (Acar, 2002: XXI) (Atak, 2016: 20-25)

Esmâ-yı Libas kasidesi, Yüsrînnin Divan'ında bulunan beş kasideden dördüncüsüdür. Aruzun $F e^{`}$ ilātün ( $F \bar{a}^{`}$ ilātün) $/ F e^{`}$ ilātün $/ \mathrm{Fe}^{`}$ ilātün/Fe'ilün (Fa'lün) kalıbıyla yazılmıştır. Bazı mısralarda vezin kusurları bulunur. 57 beyitten oluşan kasidede o dönemde kullanılan 67 kıyafet ve kumaş adına yer verilir. Klasik kaside muhtevasından farklı bir kaside olan Esmâ-yı Libâs'da şairin kıyafet adlarını tevriyeli kullanması ve yaptığı benzetmeler dikkat çekicidir. Bu sebeple kaside, giyim kuşam kültürü ve tarihi için önemli bir vesikadır. Şair, kıyafet adlarına ve özelliklerine ışık tutmanın yanında devrin gelenek ve göreneklerine dair bilgi de verir.

\title{
Osmanlı toplumunda giyim kuşam
}

Giymek sözcüğü, Türkçe Sözlük’te "Örtünüp korunmak için bir şeyi vücuduna geçirmek." şeklinde tanımlanır. (Türkçe Sözlük, 2005: 765) Bu nedenle giyinmek başlangıçtan beri, insanın temel ihtiyaçları arasında yer alır. Ancak zaman içerisinde bu ihtiyaç farklı özellikler de kazanır. Bir toplumun giyim kuşam kültürü; toplum içinde bulunan içinde bulunan etnik gruplar, dini inanışlar, coğrafi şartlar, gelenek ve görenekler gibi farklı faktörlere göre şekillenir. Kişinin cinsiyeti, yaşı, mesleği, maddi durumu, üstlendiği toplumsal roller de bir toplumun giysi çeşitliliğini artıran etmenlerdir. Bu durum giyim kuşamı, toplum yapısına ışık tutan bir kaynak haline getirir. Atilla Erden, giyim kuşamın gelişme ve çeşitlenme sürecini şu sözlerle ifade eder:

\begin{abstract}
"Giysi, insanoğlunun yaşamında önemli yer tutan, zengin içerikli kültürel bir olgudur. Başlangıçta çeşitli doğaüstü güç ve doğal etkenlerden koruma aracı olarak doğmuş ve gelişmiştir. Zamanla iklim farklılıkları, teknolojik gelişmeler, toplumların kültürel ve ekonomik yapılarındaki değişmeler, giysilerin farklı niteliklere kavuşmalarına, fonksiyonunun geniş kapsamlı boyutlar kazanmalarına neden olmuştur. Öyle ki; giysiler koruma fonksiyonlarının dışında, kişilik ve mevki belirlemede, süslenme, çevreye ve topluma uyabilmede daha ilk bakışta önemli ipuçları veren semboller kompleksine dönüşmüşlerdir. Bu oluşum giysiyi, kişinin belli boyutlarda dünya görüşünü, yaşam felsefesini, düşünce ve değer yargılarını yansıtan bir ayna niteliğine ulaştırmıştır. Dolayısıyla, bireylerden oluşan toplumların da canlı yansitıcıları olmuşlardır." (Erden, 1998: 10)
\end{abstract}

Osmanlı Devleti, kendine has ve özgün bir giyim kültürüne sahiptir. (Çetin, 1995: 4) Devletin yüzyllarca hüküm sürmesi, topraklarını genişletmesi ve toplumdaki etnik çeşitliliğin artması Osmanlı giyim kültürünü çeşitlendirmiş ve zenginleştirmiştir. Giysi, giyen kişi için bir sosyal statü göstergesidir. Farklı kültürlerin bir araya gelmesiyle oluşmuş karmaşık bir yapısı olan Osmanlı Devleti’nde giysi çeşitliliği insanların din, ırk, meslek, zenginlik açısından diğerlerinden ayırt edilmesini kolaylaştırmıştır. (Goodwin, 1997: 173) Osmanlı giyim kültürü, Türklerin Orta Asya'da göçebe yaşadığı döneme 
dayanmaktadır. Değişen koşullar Osmanlı giyim kültürünün temelinde farklılı̆̆a sebep olmamış, giyim kuşam eşyaları genel hatlarını korumuş, yalnızca detaylar değişmiştir. Osmanlı giyim kültürü devletin hüküm sürdüğü altı yüz yıl boyunca benzer biçimdeki kıyafetlerle devam eder. XIX. yüzyıldan itibaren büyük değişiklik gösterir. (Görünür ve Ögel, 2006: 61) Osmanlı giyiminin dikkat çeken bir özelliği de "kat kat" giyinmedir. Doğu kültürü giysilerine ait bu özellik, iklim koşulları sebebiyle ısınma amaçlı tercih edilir. Giysiler kat kat giyilirken, hangi sırayla neyin giyileceği bellidir ve gösterilmek istenen kumaşlar özenle seçilir. Türk giysilerinin çoğunda görülen bu giyinme biçimi zenginlik ve güç göstergesi olarak da görülebilir. (Himam, 2013: 96-97) Bu kat kat giyinme biçimi Osmanlı'da kadın, erkek ve çocuk için aynıdır. Osmanlılarda kadın, erkek ve çocuk kıyafetleri; şalvar, gömlek, iç ve dış kaftanından oluşurdu. Ölçüleri dışında kumaş ve kesimlerinde fark yoktu. (Tezcan, 2012: 1) "Kat kat" giyinme tercihi de Osmanlı giyim kültürünün zenginleşmesine katkı sağlamıştır.

\section{Esmâ-yı Libâs kasidenin muhtevası}

Yüsrî, Esmâ-yı Libâs kasidesini Osmanlı giyim kültürünün klasik özelliklerini koruduğu XVIII. yüzyılda kaleme alır. Kasidesinde toplumun farklı kesimlerince tercih edilen kıyafet ve kumaş adlarına yer verir. Esmâ-yı Libâs kasidesi bir nevi tevriye kasidesi de sayılabilir. Şair; sıkça kullandığı tevriyenin yanında teşbih, telmih, istiare, hüsn-i talil gibi söz sanatlarından da faydalanır. Yüsrî, kasideye şiir söyleyişini överek ve şiirinin konusunu açlklayarak başlar. Şair, okuyucuyu düzgün sözlerinin süs dağıtan kalemine kulak vermeye davet eder. Çünkü kıyafet adlarından oluşan şiiri cilveleriyle kendini gösterecektir.

Gūş țut ḩāme-i zīnet-dih-i endām-beyān

Naẓm-1 esmā-yı libās itse gerek cilve-künān

İkinci beyitte, şair kıyafet ve kumaş adlarına yer vermeye başlar. Şiirde kullanılan ilk kumaş adı "destmâl”dir. Dilimize Farsça'dan geçen sözcük; el silecek şey, elbezi, yağlık, peşkir anlamlarına gelir. Günlük hayatta mendil gibi üstte taşınmış, yalnızca el yüz kurulamak için değil; yüzün terini silmek için de kullanılmıştır. (Koçu, 1969: 89) Beyitte yer alan diğer kıyafet ise benzer bir işlevi olan "arak-çîn"dir. Arak-çîn, külah ile kavuğun terden yağlanıp kirlenmemesi için bu iki kıyafetin altına giyilen takkedir. Halk arasında "terlik" de denir. (Koçu, 1969: 13) Şair, bu iki kelimenin "ter"le ilgili olmasıyla bağlantı kurarak "Emellerimin gül bahçesinin çemeni suya doyar mı?” cümlesiyle istifham yapar.

Dest-māl nigeh-i āz-1 araḳ-çīnin iken

Çemen-i gülşen-i āmālim olur mı reyyān

Yüsrî, üçüncü beyitte devrinde başlık olarak yaygın kullanılan "fes" i bu kıyafetin kaynağı olarak görülen Fas'la tevriyeli olarak kullanır. Reşat Ekrem Koçu, Türk Giyim Kuşam ve Süslenme Sözlüğü’nde "fes" maddesine önemli bir yer ayırır. Kamûs-ı Türkî ve Büyük Türk Lügatïnde "Fas şehrinde icat edilmiş baş kisvesi” şeklinde tanımlanan fesin tarihi, Frikya Kralı Midas'ın Frikya külahına kadar dayanmaktadır. Müslüman olan toplumlar içerisinde fes giyen ilk topluluk Fasllar olduğu için sözlüklerde onların icadı olarak kabul edilir. Osmanlı Devleti'nde ise XVI. yüzyıldan itibaren fes giyilmeye başlanmıştır. Zamanla toplumda yaygınlaşan fes; kadın, erkek, çocuk ve her sınıftan insanın giydiği bir giyecek haline gelir. (Koçu, 1969: 113-116) Bu beyitte şair, devrinde fes kullanımının yaygınlığına ve fesin Osmanlı ülkesine Arap dünyasından geldiğine dikkat çeker.

Tā-benā-gūşa yitişdi ḩațt-1 nev-ḩīz dahı̆

İtdi maḥṣūr-1 bilād-1 Fesi hayl-i ' Urbān 
Kasidenin dördüncü beytinde, yünlü kumaş anlamina gelen "sûf/sof" ile tasavvuf ehli kişi olan "sûfî" sözcükleri tevriyeli kullanılır. Beytin ikinci mısraında, padişahlar ve gelinlerin de kullandığl; tarikat şeyhlerinin başlı̆̆ı "taç”a yer verilir. (Koçu, 1969: 220) Yüsrî; sofinin, sevgilinin dudağına âşık olmakla halka erkeklik sattı̆̆ını ve taç sahibi bir horoz olduğunu gösterdiğini söyler. Şairin bu ifadeleri edebiyatımızda sofiye karşı olumsuz tutumun bir yansımasıdır. Zahit olarak da adlandırılan sofinin eleştirilmesinin temel nedeni; soğuk, kuru bir zühd anlayışını benimsemesi, kaba ve ham sofuluğu, şekilci ve merasimci oluşu, katı ve sert dindarlığı, riyası ve yobazlığıdır. (Sucu, 2007: 233) Yüsrî de bu beyitte sofiyi şekilciliği ve riyakârlı̆̆ı sebebiyle eleştirir.

'Aş̧̣̂-1 la' linle șatar erligi halḳa șūfí

Dỉk bā-tāc-1 hurūs oldig̀in eyler iž ān

Beşinci beyitte, "gül-i âh" adlı kıyafet kullanılır. Kaynaklarda bu başlıkta bir kıyafet adına rastlanmazi73. "Âh" ise tek başına Derleme Sözlüğü’ne göre "Kadınların başlarına örttükleri beyaz tülbent." (Derleme Sözlüğü, 2009: 121) anlamına gelir. Gül-i âh bu örtünün bir çeşidi olabileceği gibi başka bir kıyafet adı da olabilir. Bununla birlikte, ilk mısrada kullanılan "Suhteganın savurur başına her dem gül-i âh" ifadesi sofilerin de başlarına giydiği "külah"ı akla getirmektedir. Şair, bu kullanımı iki kıyafeti de kastetmek üzere bilinçli olarak tercih etmiş olabilir. Külah, yüzyllar boyunca erkekler, askerler ve her tabakadan halk tarafından giyilmiş bir başlıktır. Dikişsiz, tek parça keçeden yapılır. Mevlevi külahları dışında tepesi sivridir. (Koçu, 1969: 162)

Sūhtegānıy șavurur başına her gāh gül-i āh

Yāsemen-rīz olur lālelere bād-1 hazān

Altıncı beyit de önceki iki beyit gibi tasavvufla ilişkilidir. Şair, zerrenin cisminden vazgeçerek "âfitâba" yani güneşe ulaştığını söyler. Vuslatı kolaylaştırmak için gelip geçici olan "fenâ"yı terk etmeyi öğütler. Metinde güneş anlamındaki "âfitâb" kelimesi ile "fenâyı”" sözcüklerinin üstü çizilidir. Ancak kaynaklarda "âfitâb" adını taşıyan kıyafet ya da kumaşa rastlanmamıştır. "Fenâyı̂" ise Kalenderîlerin giydikleri "fenâ" da denilen cübbe, palto gibi üstlüklere verilen addır. (Onay, 2013: 243) Beyitte tasavvufi bir terim olan "fenâ"yı terk etmek tasavvuf zümresine ait bir kıyafetle kullanılır.

Āfitāba irişür zerre mücerredlik ile

Sen de terk eyle fenāyı k'ola vuṣlat āsān

173 Aşağıdaki kaynaklarda "gül-i âh”, "âfitâb”, "gül-efser”, "köse”, "şeşkezî", "cûdî”, "kâ’im-hâne”, "mirzâyi" "burûc”, "çeşm-i bülbül”, "bâdeli kürdi” "tepe-dâr" ve "at" sözcükleri ile ilgili bilgi bulunamamıştır: Argit, B. (2015). Osmanlı İstanbul'unda Giyim Kuşam. A. Bilgin (Ed.), Antik Çă̆’darl 21. Yüzyıla Büyük İstanbul Tarihi, Toplum (c. 4 s. 230-247). İstanbul: İbb Kültür A.Ş;; Bahadır, S. C. (2015). Osmanlı Sosyal Hayatının Divan Şiirine Yansımaları. (Ed. Ö. Şenödeyici), Osmanlı Edebi Metinlerini Anlama Kılavuzu (s. 557-608). İstanbul: Kesit; Bilgen, S. (1999). Osmanlı Dönemi Türk Kadın Giyimi 16. yy19. yy, (Yayımlanmamış Doktora Tezi). Gazi Üniversitesi Sosyal Bilimler Enstitüsü, Ankara; Dağll, B. (2007). Kelime Kazanımı Üzerinde Bir Araştırma (Kıyafet ve Kumaş Adları Örneği). (Yayımlanmamış Yüksek Lisans Tezi). Marmara Üniversitesi Eğitim Bilimleri Enstitüsü, İstanbul; Devellioğlu, F. (2008). Osmanlıca-Türkçe Ansiklopedik Lügat. (Haz. A. S. Güneyçal). Ankara: Aydın; Ermert, E. (2019). Ansiklopedik Giyim-Kuşam ve Moda Sözlüğ̈̈. İstanbul: Hayalperest; Koçu, R. E. (1969). Türk Giyim Kuşam ve Süslenme Sözlüğü. Ankara: Sümerbank Kültür; Kubbealtı Lügati (26.06.2020) Erișim Adresi: http://lugatim.com/; Onay, A. T. (2013). Açklamah Divan Süri Sözlüğü Eski Türk Edebiyatında Mazmunlar ve İzahı. (Haz. C. Kurnaz). Ankara: Berikan;_Özen, M. E. (1981). “Türkçe’de Kumaş Adları”, Tarih Dergisi, İstanbul Üniversitesi Edebiyat Fakültesi Yayınları 33, 291-340; Özkan, Ö. (2005). Divan Şïrinde Sosyal Hayat (14 ve 15. Yüzyıl). (Yayımlanmış Doktora Tezi). Gazi Üniversitesi Sosyal Bilimler Enstitüsü, Ankara; Öztekin, Ö. (2004). XVIII. Yüzyıl Divan Şïirinde Toplumsal Hayatın İzleri: Divanlardan Yansıyan Görüntüler. (Yayımlanmış Doktora Tezi). Hacettepe Üniversitesi Sosyal Bilimler Enstitüsü, Ankara; Öztoprak, N. (2010). "Divan Şiirinde Giyim Kuşam Üzerine Bir Deneme", Divan Edebiyat Araştırmalar Dergisi 4, 103-154; Pakalın, M. Z. (1983). Osmanl Tarih Deyimleri ve Terimleri Sözlüğ̈̈ I, II, III. İstanbul: Milli Eğitim; Pala, İ. (2009). Ansiklopedik Divan Şiïri Sözlüğü. İstanbul: Kapı; Redhouse, S. J. W. (2006). A Turkish and English Lexicon 3. Edition. İstanbul: Çağrı; Tarama Sözlüğü I, II, III, IV, V, VI (1972). Ankara: Türk Dil Kurumu; Türkçe Sözlük (2005). Ankara: Türk Dil Kurumu; Türkiye’de Halk Ağzından Derleme Sözlüğ̈̈̈ I, II, III, IV, V, VI (2009). Ankara: Türk Dil Kurumu.

Address

Kurklareli University, Faculty of Arts and Sciences, Department of Turkish Language and Literature, Kayalı Campus-Kırklareli/TURKEY e-mail: editor@rumelide.com 
Yedinci beyitte, taç anlamına gelen "efser” sözcüğü "gül-efser” şeklinde kullanılmıştır. Kaynaklarda "gülefser” şeklinde bir kıyafet adı bulunamamıştır. "Gül-efser”in taç çeşidi olduğu düşünülebilir. Beyitte, "Meclisin şarap sürahisinin gerdanı bağlansa şaşılacak şey midir? Çünkü at başını dik tutunca [ona] gülefser takılır." ifadesi kullanılır. Beyitte kabaktan yapılmış şarap sürahisi ata benzetilmiştir. Bu nedenle "gül-efser"in at süslemede kullanılan bir aksesuar olduğu düşünülebilir.

$\mathrm{Ne}^{c}$ aceb gerdeni bağlansa kedū-yı bezmin

Çün gül-efser urılur başını dik țutsa ḥıșān

Sekizinci beyitte, kumaş ve kıyafet adı olarak "bendi” sözcügü yer alır. "Bend” ve "bendi” birer kumaş çeşididir. (Kayaokay, 2018: 525) Kelime "bandi" şekliyle kadın ayakkabısı anlamında da kullanılır. (Dağlı, 2007: 40) Şair beyitte bu kıyafetlerden birini kullanmış olabilir. Ancak beytin anlamı göz önünde bulundurulduğunda, şairin kastının kadınlara ait bir kıyafet olan "bende" olduğu görülür. Bende, kadınların boyunlarına bağlayıp el ve yüzlerini silmek için kullandığı bir mendildir. Kadınların göğüslerine gerdikleri kumaş anlamına da gelir. (Dağlı, 2007: 44) Şair, beyitte "Bağın gülünün bendi, bülbülün aklını zapt eder, gülen sevgilinin yüzü, hevesli kimseleri kul eder." ifadesine yer verir. Şair, beyitte kullanılan "bağın gülü" ifadesiyle sevgilinin göğüs ve gerdan bölgesi arasında benzerlik kurar. Böylece "bende"nin vücutta kullanıldığı yere de dikkat çeker.

Żabṭ ider hūş-1 hezārı gül-i bag̉uy bendi

Kul ider ehl-i hevāyı belī rūy-1 ḩandān

Dokuzuncu beyitte, "hünkâr" kelimesi padişah anlamında kullanılır. Kaynaklarda tek başına "hünkâr" adını taşıyan bir kıyafet bulunmaz. "Hünkâr kilidi" ve "hünkâr takkesi” şeklinde iki kıyafet vardır. Hünkâr kilidi, Sivas yöresinde kullanılan bir motifli çorap türüdür. Hünkâr takkesi ise Osmanlı padişahlarının benekli denilen kadifeden yapılmış kışa mahsus gecelik takkeleridir. (Dağlı, 2007: 136) Beytin ikinci mısraında geçen "gürz"; yuvarlaklığı ve üzerinde bulunan ufak demirler dolayısıyla, benekli bir takkeye benzetilebilir. Bu nedenle Yüsrînnin beyitte "hünkâr" sözcügünü "hünkâr takke" anlamında kullandığı düşünülebilir.

Sevenüy sen ḳulı ol sevmeyenin hünkārı

Mūra bir kelle şeker māra görün gürz-i gīrān

Onuncu beyit, Yüsrî̀nin devrinin gelenek ve göreneklerine yer verdiği beyitlerden biridir. Bu beyitte "helâlî/hilâlî" kumaşı kullanılmıştır. Şairin yaşadığı XVIII. yüzyılda ramazan ve bayram günlerini önceden belirlemek mümkün değildi. Bu nedenle ayın hareketlerini takip etmek üzere devlet tarafından bir heyet belirlenirdi. Yüksekçe bir yerden ayın hareketlerini izleyen bu heyet, hilali gördüğünde; padişah fermanıyla ramazan ve bayram günleri halka duyurulurdu. (Bahadır, 2015: 586) Yüsrî de beyitte "hilâlî" sözcüğüyle bu geleneği hatırlatır.

Rü 'yet-i ḥācibi ḥācetimi șiyām-1 hecre

Ṭutalum eyledi pinhān hilāli ramażān

On birinci beyitte, yer verilen kıyafet adı "köse"dir. Ancak kaynaklarda, "köse" adında bir kıyafet bulunmaz. Beyitte "köse" sakalı, bıyı̆̆ı çıkmayan kişi anlamında kullanılır.

Düşürür țurresin ebrūları pīç ü tāba

Köse mebḥașde ebu'l-liḥyeyi eyler șu'bān 
On ikinci beyitte, "şeşkezî" adlı kıyafete yer verilir. Ancak kaynaklarda kelimenin anlamı bulunamamıştır. Nüshalardan yalnızca birinde bu sözcüğün yerinde "şeş-geri” kelimesi bulunur. Şeşger, altıparmak kumaşının başka bir türüdür. "Şeştari, şitari, çitari, balkaymak" gibi adlarla da bilinen yollu yollu bir kumaştır. (Dağll, 2007: 249) Nüshaların çoğunluğu göz önünde bulundurarak şairin "şeşkezî" kelimesini kullandığını düşünüyoruz.

Her āteşde aluruz şeşkezī menzil-gehde

Azmāyişse gaaraż işte ḩadeng işte kemān

On üçüncü beyitte, “cûdî” adlı kıyafet adı, Nuh Tufanı'na telmih yapılarak Cudi Dağı'yla tevriyeli kullanılır. Ancak kaynaklarda "cûdı̂” adlı bir kıyafet ya da kumaş bulunmaz.

Olsa cūdī demi ṭūfān-1 kerem ṭag̀-1 dilim

Fülk-i maḳṣūdı ḳomaz vuṣlata mevc-i hicrān

On dördüncü beyitte, Osmanlı Devleti döneminde mezar taşlarına ait bir geleneğe yer verilir. Yüsrî, bu beyitte mezar taşlarına sarı konması âdetinden bahseder. Beyitte "mermer" adlı kumaş konu edilir. Mermer de denilen mermerşahi, tülbentten kalın, pamuklu, beyaz bir dokumadır. Çocuklar için iç gömleği dikmek için kullanılır. Büyükler de sarık olarak kullanır. (Dağlı, 2007: 195) Osmanlı Devleti döneminde kullanılan mezar taşları başlık, ser-levha, kimlik bilgileri, dua ve tarih bölümlerinden oluşur. Mezar taşlarının başlık kısmında, genel adı serpuş olan başa giyilen kıyafetler bulunur. Sarık da bunlardan biridir. (Sipahi ve Çetin, 2010: 233) Mermerden yapılan mezar taşlarının üzerine sarık işlenir. Toplumun her kesiminde sarık giyilse de bu başlık ulema ile özdeşleşmiştir. (Bozkurt, 2009: 154) Yüsrî, bu beyitte mezar taşlarına sarık konmasını, ölen kişilerin "mermer sarınması" olarak adlandırır. Ölen kişinin sevgilisinin gücünü göstermek adına böyle yaptığını söyleyerek de hüsn-i talil yapar. Mezar taşlarına sarık konması geleneği XIX. yüzyılın ilk çeyreğinde II. Mahmud'un getirdiği yeni kıyafet kanunuyla yerini fese bırakır. (Sipahi ve Çetin, 2010: 233)

Küştegānuy çoġı mermer șarınur maḳberede

Başı pekligini dildārınuy eyler i‘ lān

On beşinci beyitte, "kâc im-hâne" sözcüğü kullanılır. Kaim; ayakta duran, bir şeyin yerine geçen, namaz kılan anlamlarına gelir. Ancak, "kâ‘ im-hâne" sözcüğünün anlamı kaynaklarda bulunamamıştır. Beyitte geçen meyhane, veli ve mescid sözcükleri adı geçen kıyafetin tasavvuf kültürüne ait olduğunu düşündürür.

Ḳā'im-ḩāne-geh-i ḳā' id-i mey-ḩāne velī

Künc-i mescidde alur uyḳuyı zerrāḳ-1 zamān

On altıncı beyitte, günümüzün giyim eşyalarından biri olan "gömlek" kelimesi kullanılır.

Çün hezārān nuḳūd-1 dile oldun mālik

Beni gömlek yirine hāakle ey ḩ̌āce amān

On yedinci beyitte, bugün entari şekliyle kullandığımız "anter̂̂" kelimesi vardır. Bu kıyafet hem erkek hem de kadın giyiminde kullanılır.

Pīzen-i ‘ aḳlı zebūn eyledi siḥr-i nigehin

Rāh-1 zenlikde ise 'anterī geçdi müjgān 
On sekizinci beyitte, "kapama” ve "kutnî" kelimeleri kullanılır. Kapama sözcüğü; elbise takımı, hırka, manto, yelek gibi pek çok kıyafet için kullanılır. (Dağlı, 2007: 154) Beyitte kapama sözcüğü, "kapamak" eyleminin olumsuzu şeklinde kullanılır. Kutnî, ise yaygın olarak "kutnu" şeklinde kullanılan pamuklu bir kumaştır. (Dağlı, 2007: 180)

Sāḳīyā gel ḳapama ḳutnī fem-i mīnāya

Eyleme dīde-i șahbā-keşi gör dü cihān

On dokuzuncu beyitte, "sade" sözcüğü süssüz, yalın anlamında kullanılır. "Sade”; astarsız, tek kat süssüz elbise anlamına gelir. (Dağll, 2007: 231)

Ḩālden sāde ider naḳş-1 mușavver ruhụı

Bì-nuḳaṭ nāmeyi daḩı güzel oḳur yārān

Yirminci beyitte, "bey, bey oğlu" anlamlarına gelen "mîrzâ" sözcüğü "mîrzâyi” şeklinde kullanılır. Kaynaklarda "mîrzâyi” adında bir kıyafet yoktur.

Künc-i çeşmünde ider ġamze-i tātārına yer

Niçe mīrzāyı bucagia ṣoḳar ol hāan-1 zamān

Yirmi birinci beyitte "burûc" kelimesi kullanılır. Kaynaklarda "burûc" adlı bir kıyafet ya da kumaş adına rastlanmaz. Beyitte, sevgilinin dudağı, ağzı ve mey sözcüklerinin kullanılması "burûc"un sevgilinin yüzünü örten bir kumaş olabileceği fikrini verir.

Hīç burūc çekilür mi mey eyā ḥoḳḳa dehen

Ne revā mầ'il-i ma'cūn-1 lebün ag̉laya ḳan

Yirmi ikinci beyitte, "taraklı şal" ifadesine yer verilir. Taraklı, eskiden kullanılan bir giysi adı olmasının yanında tarak dişleri gibi yollu çubuk desenli kumaş anlamına gelir. (Dağlı, 2007: 254-255) Şal da taraklı gibi hem kumaş hem giysi adıdır. Omuza ve başa örtülen kumaşlara ve kadınların kullandığı başörtüsüne şal adı verilir. (Dağll, 2007: 246) Şair beyitte; sevgilinin saçındaki meşşataya ait tarağın görüntü olarak bakır renkli, taraklı kumaştan yapılmışşala benzetilebileceğini söyler.

Beyzedürse n'ola jengāri țaraḳlı şāla

Her gören şāne-i meşşāṭayı zülfünde ' ayān

Yüsrî, yirmi üçüncü beyitte "alaca" kumaşının adına yer verir. Beşparmak adı da verilen bu kumaş kırmızı zemin üzerine sarı çubukları olan karışık renkli bir kumaştır. (Dağlı, 2007: 28) Şair, beyitte kumaşın renk özelliğinden faydalanarak ikiyüzlü, kötü kalpli kişi anlamına da gelen alaca kelimesini kullanır. Anlamı güçlendirmek için siyah beyaz renkli atlar için kullanılan "ablak" kelimesine yer verir. "Ablak-ı çarh" yani "feleğin alaca atı" tabiri Selçuklulardan kalma bir tabirdir. Anadolu Selçuklu sultanı Alaaddin Keykubad tahta çıkış töreni esnasında törenin atlı kısmını başlatmak üzere "zamanın alaca atı”na binmeye davet edilmiştir. (Esin, 2004: 271) Yüsrî, beyitte kötü kalpli olan kişinin devrin sultanı bile olsa bir şey elde edemeyeceğini ifade eder.

Ablaḳ-1 çarha süvār olsa da ḳalbi alaca

Yine menzil alamaz itse ne dẹlü cevelān 
Yirmi dördüncü beyitte, “çeşm-i bülbül” ve "tuman” sözcüklerini kullanır. Kaynaklarda "çeşm-i bülbül” adlı bir kıyafete rastlanmaz. Kayaokay, “çeşm-i bülbül”ün kıymetli bir kumaş olduğunu söyler ancak kaynak göstermez. (Kayaokay, 2018: 525) Çeşm-i bülbül, III. Selim ve Abdülmecid zamanında Beykoz ve Paşabahçe'de açllan fabrikalarda üretilen günümüzde antika değeri taşıyan, helezonî çizgili veya hareli, renkleri son derece ahenkli, çok ince cam eşyanın adıdır. Bu ismin, eşyaya desenlerinin bülbülün gözündeki halkalara benzetilmesi sebebiyle verildiği düşünülmektedir. (Kubbealtı Lügati, Erişim tarihi: 20.05.2020) XVIII. yüzyılda kaleme alınan kaside de bu ifadenin kullanılması, bir kıyafet ya da kumaşın cam eşyanın adı konulurken ilham olabileceğini düşündürür. Beyitte kullanılan diğer kıyafet adı ise şalvar anlamındaki "tuman"dır. Şair, bu kelimeyi "gülün işi tuman" şeklinde işi zor anlamında duman sözcügüyle tevriyeli kullanır.

İdemez șarf-1 nigeh eşkle çeşm-i bülbül

Şebnem-i çarhlla gülşende gülüy işi țuman

Yirmi beşinci beyitte, "peşm”, "bâdeli kürdi”, "girîbân” ve dâmân” adlı kıyafetlere yer verilir. Peşm, yün anlamına gelir. Girîbân gömlek, dâmân ise etektir. Ancak nüshalardan birinde "yâdeli" şeklinde yazılan "bâdeli kürdi" hakkında herhangi bir bilgiye ulaşlamamıştır. Şairin otuz ikinci beyitte kullandığı "kadın ceketi, hırkası" anlamındaki "kürdiye” adlı kıyafetin bir çeşidi olduğu düşünülebilir.

Peşmi ḳoymaz ‘ acabā derzi bizüm cāmemize

Bādeli kürdi girỉbānına döndi dāmān

Yirmi altıncı beyitte, "tepe-dâr" adlı kıyafet kullanılır. Kaynaklarda herhangi bir bilgi bulunmasa da -dâr ekinin "tutan" anlamından yola çıkarak ve beyitte kullanılan "başıma teng oldı cihân" ifadesi sebebiyle "tepe-dâr”n bir başlık çeşidi olduğu düşünülmüştür.

Dilde tașvīr ideli žātını Bihzād-ı hayāl

O tepe-dārı benüm başıma teng oldı cihān

Yirmi yedinci beyitte Mevlevi dervişlerine ait "tennûre" adlı giysi adı kullanılır. Tennûre, Mevlevi dervişlerin sema törenine çıkarken giydikleri kolsuz, yakası yırtmaçlı uzun bir entaridir. (Dağlı, 2007: 258) Şair, beyitte tennûre kelimesini tenin nura gark olması anlamıyla kullanır. Zikreden dervişlerin terlemesini de zikir yapmalarına değil, sevgiliye sarılma sebebine bağlayarak hüsn-i talil yapar.

Ġarḳ olur ol mehi āgūsşa çeken ten nūra

Șanma beyhūde ' araḳ-rīz olur ehl-i devrān

Yirmi sekizinci beyitte, hem "yazlık" ayakkabı hem de ipekli kumaş adı olan "sandal” sözcügü kullanılır. Avrupai bir ayakkabı olan sandal Osmanlı ülkesinde 1908'den sonra yayılmıştır. (Dağlı, 2007: 233) Bu nedenle şairin, beyitte kumaş olan "sandal” kullandığı düşünülmektedir.

Nīl-i mażmūna cerīm old 1 ise țab ${ }^{\complement}-1$ selīm

Ḩāme șandāl aya bārīk-i ḩayāl oldı lebān

Yirmi dokuzuncu beyitte, İran'dan ithal edilen bir kumaş olan "dârâyi" kelimesi kilise çanı olan "derâ/derây" ile tevriyeli olarak kullanılır. Dârâyi çeşitli renkler üzerine kalın eski bir kumaşın adıdır. Şam'da dokunan benzerlerine "Şam dârâyi”si diğer bir çeşidine ise "Pülâdî dârâyi” adı verilir. (Koçu, 1969: 86) 
Ey șanem ma' bed-i İslām-1 derāyı neyler

Ne belā idi bizim başımıza bu efğān

Otuzuncu beyitte, "kuşak" ve "tolama" birlikte kullanılır. Beli sarmak için kullanılan "kuşak" kuş ağı şeklinde, belden kuşakla tutturulan cübbe anlamındaki "tolama" sözcügü ise "dile dolamak" eyleminin olumsuzu şeklinde kullanılır. Şair, beyitte "Kuş ağı sarhoş erkek aslanı avlayamaz. İhsan et bizi zahid diline dolama." diyerek zahide karşı olumsuz tutumunu sürdürür.

Kuş ag̀ı șayd idemez şîr-i ner-i ser-mesti

Bizi zāhid dilüne țolama eyle iḥsān

Otuz birinci beyitte, önceki beyitteki gibi bele sarılan kumaş anlamındaki "kemer-bend" kullanılır.

O mehe hāle-i àgūş-1 kemer-bend yiter

Şāmdan neyler ider 'azm-i reh-i Hindistān

Otuz ikinci beyitte, şair devrin müzik kültürüne de hâkim olduğunun gösterir. Beyitte geçen "kürdiye" kelimesini müzik makamı olan "kürdı̂" ile tevriyeli kullanır. Kürdiye; Derleme Sözlüğ̈̈̈ne göre kadın ceketi, uzun hırka anlamlarına gelir. (Derleme Sözlüğü, 2009: 3044) "Kürdü” şeklinde de kullanılır. Kürdünün yeldirme anlamı da vardır. Şair, beyitte müzikte bir usulün adı olan "evfer" sözcüğüne de yer verir.

Nağme-i kürdiye çevirir be-ușūl-i evfer

Eylesem eşk-i pür-efşān ile āheng-i fig̀ān

Otuz üçüncü beyitte, bugün de kullanılan “yelek” yer alır. Yelek sözcügü beyitte kanatlanmak, kanat açmak anlamına gelen "yeleklenmek" eylemi şeklinde kullanılır. (Türkçe Sözlük: 2005: 2160)

Uçdı ḩațtıla yeleklendi ḩadeng-i hüsni

Kāmetüm ḳabża-i cevrinde daḩı şekl-i kemān

Otuz dördüncü beyitte, mintan anlamına gelen "nîm-ten" sözcügü yer alır. Nîm (yarım) ve ten (beden) sözcüklerinin birleşmesiyle oluşan bu kelime, beyitte incelik ve zayıflık yönüyle "meh-i neve" yani hilale teşbih edilerek kullanılır. Beyitte, sevgilinin kaşlarının hasretini çeken aşıkların yeni ay gibi zayıflayıp inceldiği ve "nîm-ten” kaldı̆̆ı söylenir.

Nim-ten ḳaldı meh-i nev gibi çarh-1 gamda

Şimdi ḥasret-keş-i ebrūlaruy ey mihr-i cihān

Otuz beşinci beyitte, ulemâ sınıfına ait bir kıyafet olan "biniş̧" kullanılır.

Biniş eyler ḳavl ile cām eger düzd-i elem

Olsa ġāret-fiken-i şehr-i derūn-1 mestān

Otuz altıncı beyitte, "kaput" kelimesi kullanılır. Şair, sevgilisine "Ey servi gibi salınan [sevgili] hüzünler evime teşrif etseydin kapıda ayağına sarılırdım." diye seslenir. Beyitte "kapuda" sözcüğüyle kapı ve palto ve kumaş anlamınla kullanılan kaput kastedilir. Şair, evinden "külbe-i ahzân" diye bahsederek Hz. Yakup'a telmihte bulunur. 


\author{
Eylesen külbe-i aḩzānıma teşrīf eger \\ Șarılurdım ḳapuda pāyına ey serv-i revān
}

Otuz yedinci beyitte, "serhaddî” sözcüğü kullanılır. Bu kelime, hem yüksek rütbeli kişilerin kullandığı samur kürk anlamında hem de sınır boylarında bulunan askerlerin kullandığı etekleri ancak dizlere kadar inen kısa kürk anlamına gelir. (Dağll, 2007: 237) Yüsrî beyitte, "Biz bu ser-haddi niçe bekleyelim sultanım diyerek" kelimenin sınır boyu, hudut anlamından da faydalanmıştır.

Biz bu ser-ḥaddi niçe bekleyelim sulțānım

Kalmadı ḳal'a-i țāḳatde mühimmāt-1 tüvān

Otuz sekizinci beyitte "ferâce" sözcüğ̈̈ "kerr ü fer" söyleyişinin içinde kullanılır. Ferace günümüzde de kullanılan kıyafetlerden biridir. Akla ilk olarak kadın giysisi gelse de ferace, ilmiye ve sınıfı ve saray erkânı tarafından kullanılan kıyafetlere de ad olmuştur. (Dağlı, 2007: 105-106)

Ziver-i bār u ber olaydı dıraht-ı ecvef

Kerr ü ferrāca bu vādīde olurdı şāyān

Otuz dokuzuncu beyitte samurdan yapılmış kürk olan "semmûr" sözcüğü "sem" zehir ve "mûr" karınca anlamlarına gelecek şekilde kullanılır. Şair, sevgilinin kâkülünü zehirli yılana, ayva tüylerini ise karıncaya benzetir. "Yılan zehri karıncaya koku ile tesir etseydi yeni çıkmış tüyleri kâkülünden kurtulabilir miydi?" diye sorar.

Eylese şemm ile semm mūre eserer ef ${ }^{\mathrm{i}}$ iden

Kākülünden hatṭt-1 nevhīz bulur mıdı emān

Kırkıncı beyit, günümüzde de devam eden bir gelenekten bahseder. Beyitte kullanılan "paça” sözcüğü; pantolon, don, şalvar gibi kıyafetlerde bacakların çıktığı alt bölüm; bağlama şalvarların altına giyilen bir tür don ve şalvar gibi anlamlara gelir. (Dağll, 2007: 213) "Kafa" ise tülbent için kullanılır. (Dağll, 2007: 149) Beyitte şair, paça kelimesiyle paça çorbasını kasteder. Paça çorbasının sarhoşluk nedeniyle çekilen baş ağrısına iyi geldiğini belirtir. Bu gelenek günümüzde de içki üzerine işkembe ve kelle paça çorbalarının içilmesi şeklinde devam etmektedir. Şair, hem iki kıyafet adına yer verir hem de Osmanlı toplumunda bezm kültürüne dair bir geleneği gösterir.

Mey-keşün paça ḳafasında ḳomaz derd-i humār

Düşse ayag̉a n'ola ġam-keş-i lā‘ 1-i cānān

Kırk birinci beyitte, sansar cinsi küçük bir hayvanın postundan yapılan "zerdevâ" kürkü yer alır. (Koçu, 1969: 249) Bir zenginlik belirtisi olan bu kürk beyitte, "Zer devâ-yı maraz-ı fakr idigin bilir.” şeklinde kullanılmış ve kürkün altın gibi değerli olduğu şair tarafından belirtilmiştir.

Zer devā-yı maraż-ı faḳr idigin fehm eyler

Yüz ḳızardır kerem erbābına cerrār-1 zamān

Kırk ikinci beyitte, küçük cinsli bir tilkinin derisinden yapılan "karsak" kürkü kullanılır. (Dağlı, 2007: 156) “Karsak” sözcüğü beyitte arak ve bâdenin karıştırılması anlamında kullanılmıştır.

Lebi ževḳiyle olan eşk-i terị neşvesini

Beyzedürdük 'araḳı bādeye ḳarșāḳ ne zamān 
Kırk üçüncü beyitte, yine bir kürk türü olan "nâfe" kelimesi kullanılır. Bu kürk; samur, tilki, tavşan gibi hayvanların karın bölgesinden elde edilir. Elde edildiği hayvanın adı ile birlikte kullanılır. Nâfe samur kürk, nâfe vaşak kürk gibi. (Dağll, 2007: 203)

Huande ḳavḳ-1 çemenistān-1 ḩațādur nāfe

Zülf-i pür-çinüne teşbīh iden eyler 'ișyān

Kırk dördüncü beyitte, sincap derisinden yapılmış "sincâb" kürk yer alır. Rengi kurşunidir. Bu nedenle kurşuni renk için "sincâbî” de kullanılır. (Koçu, 1969: 206)

Șunasın cābe müdāmāne revā cāmı bize

İtmedi Cem dahı bu hürmeti ey pīr-i mugàān

Kırk beşinci beyitte, "ton” "al” ve "at” kıyafet adları kullanılır. Günümüzde de kullanılan don şekliyle kullanılan "ton” sözcüğü iç çamaşırı ve elbise anlamına gelir. "Al” ise düğünde damadın boynuna takılan kırmızı bez, kadınların alınlarına bağladıkları ipek kumaş ve gelinlerin başına örtülen uzun kırmızı örtü anlamlarına gelir. (Dağll, 2007: 28) “At” sözcüğünün ise tek başına bir anlamı yoktur. "At göğüslüğü” ve "At uşağı fesi” şeklinde iki kıyafet adı vardır. Bunlardan ilki, bir çeşit çorap nakışı; ikincisi ise Abdülaziz Han'ın (1861-1876) at uşakları tarafından giyilmiş festir. (Dağll, 2007: 34) Bu nedenle Yüsrî̀nin beyitte "at" sözcüğüyle hangi kıyafeti kastettiği anlaşlamamıştır. Şair, beyitte "ton” sözcüğünü "at tüyünün rengi" anlamıyla kullanarak tevriye yapar.

Mā 'ilim bir țonı āl ata ele girmez ise

Yine sāḳi mey-i gülgūnuna ḳalur meydān

Kırk altıncı beyitte, ayağa giyilen ve günümüzde de kullanılan “terlik” kelimesi tazelik anlamıyla tevriyeli olarak kullanılır.

Bāèg-1 hüsnün giderek bād-1 ḩazānīde eser

Sen bu terlikle mi ḳalsan gerek ey gonce dehān

Kırk yedinci beyitte "çakşır" kelimesine yer verilir. Şair; geniş pantolon, kıldan dokunan şalvarlık kumaş anlamlarına gelen "çakşır" "çakmak eylemi ve aslan anlamındaki "şîr" kelimesiyle tevriyeli kullanır. Beytin ikinci mısranda "Zühre-i sevr-i felek" ifadesi yer alır.

İçelüm bādeyi çāḳ şīr-i jiyāna dönelüm

Yaralum Zühre-i șevr-i felegi na' re-zenān

Yüsrî bu beyitte, Zühre yıldızından ve Sevr burcundan bahseder. Divan edebiyatında astronomide Batlamyus sistemi esas alınır. Bu sisteme göre dünyayı kuşatan 9 felek vardır. Ay, Utarid, Zühre, Şems, Merih, Müşterî, Zuhâl gezegenleri ilk yedi feleği oluşturur. Sekizinci felekte ise burçlar bulunur. Dokuzuncu felek ise bütün felekleri kapsayan en büyük felektir. (Yıldırım, 2015: 342) Burçların bulunduğu sekizinci felekte sabit yıldızlarda bulunur. Bu yıldızlardan Zühre Müşteri’nin uğurlu olduğu kabul edilir. On iki burçtan biri olan Sevr (boğa) burcu Zühre yıldızına aittir. (Ağbal, 2012: 258) Sevr kelimesinin anlamından dolayı bu burç edebiyatımızda ağır yükleri ve feleği taşıma özelliğiyle kullanılır. (Ylldırım, 2015: 346) Yüsrî de bu beyitte şarap içip kükreyen bir aslana dönüşerek feleğin öküzünün karnını yaralım der. Şair, beyitte hem Zühre yıldızındaki Sevr burcundan bahseder hem de dünyanın 
öküzün boynuzunda taşındığı inancına telmihte bulunur. "Zühre” beyitte "öd” anlamına gelen "zehre" sözcüğüyle tevriyeli kullanılır.

Kırk sekizinci beyitte, ayağa giyilen ve günümüzde de kullanılan “çizme” çizmek eyleminin olumsuz şekli olarak tevriyeli kullanılır.

Çizme pergār-ṣıfat ey dil-i pūyān-1 kenār

Vasaṭ-1 dā 'ire-i vefḳ olur ḳuṭba mekān

Kırk dokuzuncu beyit mahlas beytidir.

Yüsrīyā çün der-i șanduḳa-i țab` 1 açdım

Alabildigi ḳadar elbise alsun yārān

[Ey Yüsrî, mizacımın sandığının kapağını açtım. Dostlar alabildiği kadar elbise alsın.] Şair, bu beyitte de giysi anlamına gelen libas kelimesinin çoğulu olan "elbise" sözcüğünü kullanır. Yüsrî, "sanduka-i tab`1 açdım” diyerek kıyafet adlarıyla yazdığı şiirle, şairliğini ortaya koyduğunu ifade eder. Kıyafetlerin saklandığı sandığın açılması, hem Yüsrî̀nin yeteneğinin ortaya çıkması hem de kıyafet adlarının görülmesi şeklinde kullanılır. Yüsrî, dostların elbise alması ile de hem şiirindeki kelime çeşitliliğini vurgular hem de diğer şairlerin kendisinden öğreneceği şeyler olduğunu ifade eder.

Ellinci beyitte, sözü uzatmamasının nedeninden söz eder.

İtmedümse n'ola tațvīl-i kelāma rag̉bet

Çün ḳubūr yeylisin ister sözin ebnā-yı zamān

Yüsrî sözü uzatmaya rağbet etmemesinin sebebini, zamanın insanlarının sözün "kubûr yenlisini" istemesine bağlar. Kubûr, sahtiyandan yapılmış enli bir kuşaktır. Gömlek kollarındaki düğmelenecek yer anlamında da kullanılır. (Derleme Sözlügüu, 2009: 2989) Kubûr sözcüğü, dar olan elbisenin bacak ve kolu için "dar" anlamında da kullanılır. (Pakalın, 1983: 309) "Kubûr kol” ifadesi kolun darlığını belirtir. Yen ise giysi kolu, kol ağzı anlamına gelir. Beyitte "kubûr" sözcüğü yenle birlikte "dar kollu" anlamında kullanılır. Yüsrî, zamane insanlarının sözün uzatılmasından hoşlanmadığını, kısa söz istediklerini "dar kol" ifadesiyle belirtir. Beyitte "kubûr" sözcüğü kabirler anlamıyla tevriyeli kullanılır. Kabirde giyilen kefen "yakasız yensiz gömlek" şeklinde tarif edilir. Yüsrî, zamanın insanlarının dünya malına değer verdiğini ve kabire de dünya malıyla gitmek istediklerini ifade eder.

Elli birinci beyitte, Yüsrî kıyafetleri saklamak için kullanılan kumaş anlamındaki "bohça" sözlüğünü kullanır. Metinde bu ikilemenin üstü çizili olmasa da şairin bu sözcüğü bilinçli kullandı̆̆ açıktır. Velinimetimize her an "bohça bohça teselli hediyeleri sunalım" diyerek adını vermeden Köprülü-zâde Es'ad Paşa'dan bahseder.

Bog̣ça bog̣ça tuhaf-1 tesliye 'arż eyleyelim

Şāhid-i sem`-i veliyyu'n-ni` amìye her ān

Elli ikinci beyitte, "hil'at" kelimesini kullanır ve Es' ad Paşa'dan bahsetmeye devam eder. Hil' ‘at, padişah ve vezirler tarafından birine mükâfat olarak giydirilen kumaş ya da kürkten yapılmış kaftandır. XVI. yüzyılda başladığı tahmin edilen bu gelenek 1826 yılında II. Mahmud tarafından kaldırılır. (Koçu, 1969: 
130) Yüsrî, Es‘ad Paşa’yı “sabrın süslü hil'atiyle örtünmüş, kullarına sonsuz nimetler veren Allah’ın takdirine razı olan biri” şeklinde tarif eder.

Ya nīi ol müddeșir-i ḩil' at-i zībā-y-şekīb

Rāżi-i ḳımet-i taḳdīr-i cenāb-1 mennān

Elli üçüncü beyit, Köprüli-zâde Es'ad Paşa'nın adının zikredildiği beyittir. Bu beyitte kıyafet adı olarak "çarkab"a yer verilir. Çarkab kıymetli bir kumaş türü ve ipekten ya da yünden dokunan kuşak anlamlarına gelir. (Dağll, 2007: 66) Şair, Es‘ad Paşa'ya “eşsiz bir inci” ve “irfan ülkesinin çarkab giymiş şahı " diyerek ondan övgüyle bahseder.

Köprüli-zāde yegāne güher Es``ad Paşa

Lābis-i çargaab-1 şāh-1 mülk-i c irfān

Elli dördüncü beyitte, "kabâ" isimli kıyafet kullanılır. Kabâ; cübbe, geniş libas, önü daima açık duran, kapanmayan en üste giyilen kaftan anlamlarına gelir. (Dağll, 2007: 148)

Ṣıḳsa her çend anı tengī-yi ḳabā-yı şiddet

Vüs` at-i șabrı ider ol ḳadar ị̣sān Sübḥān

Elli beşinci beyitte, "kabaniçe" ve "ferace”ye yer verilir. Kabaniçe, hükümdarların şahsına mahsus bir kürk çeşididir. Bazen çok büyük bir iltifat eseri olarak sadrazamlara huzura çıktıkça giydirilirdi. (Dağll, 2007: 148) Beyitte "Bu kabâ niçe şahânın bedenin kuçmışdur" şeklinde bir önceki beyitte kullanılan "kabâ" ile tevriyeli kullanılır. İkinci mısrada kullanılan "fürce" kelimesi kökünden gelir. Bu kelimeyle otuz sekizinci beyitte kullanılan "ferace" adlı kıyafet kastedilmiş olabilir. Ayrıca Kubbealtı Lügati'nda "ferecî" adlı bir kıyafetten bahsedilir. Bu kıyafet şeylerin ve ulemaların giydiği çok geniş ve bol bir üstlüktür. Yüsrî beyitte bu iki kıyafeti de kastetmiş olabilir. (Kubbealtı Lügati, ferecî, Erişim tarihi: 20.05.2020)

Bu ḳabā niçe şahānın bedenin ḳuçmışdur

Fürce-i şiddet ile vāṣıl olur ādem olan

Elli altıncı beyitte, "hârâ" kelimesi kullanılır. İpekli bir kumaş türü olan "hârâ" beyitte sert anlamıyla tevriyeli kullanılır. Yüsrî beyitte zikrettiği elbiselere ve dünya malına değer vermediğini belirtmek üzere "Bu zamanda sert taş gibi yolunda çıplak ölsek de elbise arzusuna düşmeyiz." ifadelerini kullanır.

Düşmezüz dāc iye-i elbiseye bu demde

Seng-i ḩārā-veş ölürsek de yoluyda ‘ üryān

Yüsrî, kasidenin son beytinde orada yaşadığı ya da bir süre kaldı̆̆g düşünülen Resmo'nun adını zikreder. Şair, bu beyitte kıyafet adı olarak "demirkoparan" anlamına gelen "timur koparan"a yer verir. Demirkoparan, mavi çuhadan yapılmış işlemeli bir ceket, yelek türüdür. (Dağll, 2007: 82)

Vāṣıl-1 sāḥil-i āmāli ider fülk-i dilin

Lā-cerem iskele-i Resmo'da tīmūr ḳoparan

\section{Sonuç}


XVIII. yüzyılda yaşamış olan Yüsrî̀nin hayatı ve eserlerine dair bilgi bulunmasa da şairin Divan'ı incelendiğinde özellikle kasidelerinde; Divan şiirinin klasik kalıpları dışına çıkan, yenilik ve farklılık arayışında bir şair olduğu söylenebilir. Yüsrî’nin şiirleri, bilgili, Arapça ve Farsça'y iyi bilen bir şair olduğunu gösterir. Yüsrî, içinde yaşadığı toplumun geçmişine, gelenek ve göreneklerine de hâkim bir şairdir.

Esmâ-yı Libas, Yüsrî̀nin giyim alanına ait terimlerle yazdığı bir kasidedir. Şair, kasidede başta tevriye olmak üzere, teşbih, telmih, hüsn-i talil gibi söz sanatlarından faydalanır. Yüsrînnin bu manzumesi devrinin giyim kuşam kültürüyle birlikte gelenek ve görenekleri hakkında bilgi vermesi bakımından da önemlidir. Yüsrînnin kullandığı ifade ve kavramlar, şairin Türk kültür, inanış ve geleneklerini iyi bildiğini gösterir.

Esmâ-yı Libâs kasidesiyle ilgili daha önce yapılan çalışmalarda, kasidede 54 kıyafet adına yer verildiği söylenmiştir. Ancak çalışmamız sonucunda şairin 57 beyitten oluşan kasidede toplumun farklı kesimlerince kullanılan 67 kıyafet ve kumaş adına yer verdiği görülmüştür. Şairin ikinci beyitten itibaren eserinde zikrettiği kıyafet ve kumaşlar metindeki sırasıyla şöyledir: Dest-mâl, arak-çîn, fes, sûfî, tâc, güli âh, âfitâb, fenâyî, gül-efser, bende, hünkâr, hilâlî, köse, şeşkezî, cûdî, mermer, kâ‘im-hâne, gömlek, anterî, kapama, kutnî, sâde, mîrzâyi, burûc, taraklı şal, alaca, çeşm-i bülbül, tuman, peşmi, bâdeli kürdî, girîbân, dâmân, tepe-dâr, tennûre, sandal, dârâyî, kuşak, tolama, kemer-bend, kürdiye, yelek, nîm-ten, biniş, kaput, ser-haddi, ferâce, semmûr, paça, kafa, zerdevâ, karsak, nâfe, sincâb, ton, al, at, terlik, çakşır, çizme, elbise, kubûr yenli, hil'at, çargab, kabâ, kabânîçe, ferace, hârâ, tîmûr koparan. Bu kiyafet ve kumaşlardan "gül-i âh, âfitâb, gül-efser, köse, şeşkezî, cûdî, ka im-hâne, mîrzâyi, burûc, bâdeli kürdî, çeşm-i bülbül, tepe-dâr, at” ile ilgili kaynaklarda herhangi bir bilgiye rastlanmamıştır. Yüsrînnin adını verdiği bu kıyafet ve kumaş adları giyim kuşam literatürümüze katkı sağlayacaktır.

\section{Esmâ-yı Libas kasidesi transkripsiyonu}

Esmâ-yı Libâs kasidesinin nüsha karşılaştırmalı metni; İstanbul Üniversitesi Kütüphanesi No. T.2912 (İ1), İstanbul Üniversitesi Kütüphanesi No. 2841 (İ2), Millet Kütüphanesi Ali Emîrî Efendi Manzum Eserler No. 515 (M1), Topkapı Sarayı Türkçe Yazmaları No. H. 966 (T1), Yapı Kredi Sermet Çifter Araştırma Kütüphanesi Türkçe Yazmaları No. 688/1 (Y1) nüshalarından faydalanılarak oluşturulmuştur. Metinde tercih edilen kelimenin aynı olduğu nüshalar yazılmamış, farklı olan nüsha dipnotta gösterilmiştir. 


\section{[í1 5b] [i̇2 6a] [M1 9a] [T1 6b] [Y1 6b] Esmā-y1 Libās1 Müştemil Ḳasīide ${ }^{174}$}

$\mathrm{Fe}^{c}$ ilātün ( $\mathrm{Fā}$ ' ilātün) / $\mathrm{Fe} e^{c}$ ilātün/ $\mathrm{Fe}^{c}$ ilātün/Fec ilün ( $\mathrm{Fa}^{c}$ lün)

1. Gūş țut ${ }^{175}$ ḩāme-i zīnet-dih-i endām-beyān

Naẓm-1 esmā-yı libās itse gerek cilve-künān

2. Dest-māl nigeh-i āz-1 araḳ-çīnin iken

Çemen-i ${ }^{176}$ gülşen-i āmālim olur $m ı$ reyyān

3. Tā-benā-gūşa yitişdi haț̣t-1 nev-ḩ̄iz ${ }^{177}$ dahy ${ }^{178}$

İtdi maḥṣūr-1 bilād-1 Fesi huayl-i ${ }^{179}$ ' Urbān ${ }^{180}$

4. 'Aşș-1 la' linle șatar erligi ḩalḳa șūfi

Dỉk bā-tāc-ı hurūs oldıġın eyler ižc ān

5. Sūhntegānı̀ șavurur başına her gāh gül-i āh

Yāsemen-rīz olur lālelere bād-1 ḩazān

6. Āfitāba irişür žerre mücerredlik ile

Sen de terk eyle fenāyı k'ola vuṣlat ${ }^{181}$ āsān

7. $\mathrm{Ne}^{\mathrm{c}}$ aceb gerdeni bağlansa kedū-yı bezmin

Çün gül-efser urılur başını dik țutsa ḥıșān ${ }^{182}$

8. Żabṭ ider hūş-1 hezārı gül-i bag̀ı ${ }^{183}$ bendi

Kul ider ehl-i hevāyı belī rūy-1 ḩandān

[Y1 7a]

9. Sevenin sen ${ }^{184}$ kulı ol ${ }^{185}$ sevmeyenin hünkāri ${ }^{186}$

Mūra bir kelle şeker māra görün gürz-i girān

10. Rü 'yet-i ḥācibi ḥācetimi șyām-1 hecre

Ṭutalum eyledi pinhān hilāli ramażān

[i் 6b]

11. Düşürür țurresin ebrūları piç ü tāba

Köse mebḥaśde ebu'l-liḥyeyi eyler șu'bān ${ }^{187}$

[T1 7a]

12. Her āteşde aluruz şeşkez $\overline{\mathbf{i}}^{188}$ menzil-gehde

Azmāyişse garaż işte hyadeng işte kemān

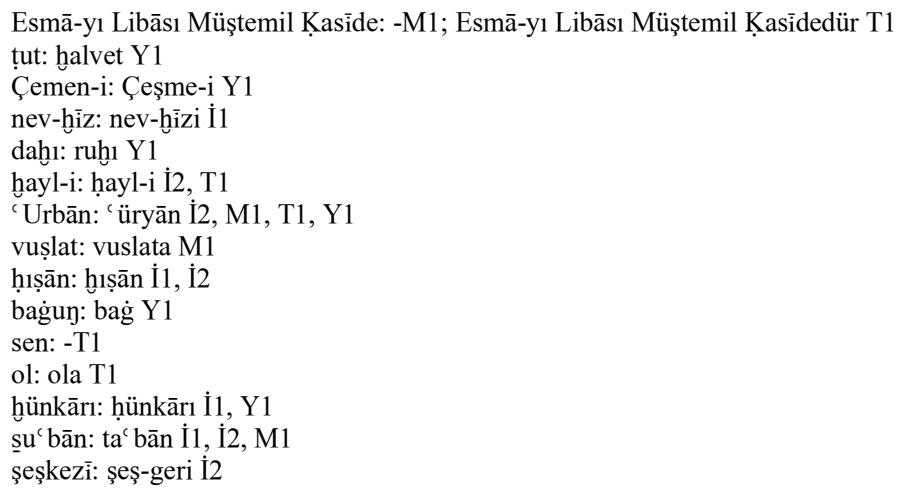


13. Olsa cūdī demi țūfān-1 kerem țag̀-1 dilim

Fülk-i makṣūdı ḳomaz vuṣlata mevc-i hicrān

[M1 9b]

14. Küştegānı̀ çog̉ı mermer șarınur maḳberede ${ }^{189}$

Başı pekliginini ${ }^{190}$ dildārının eyler i' lān

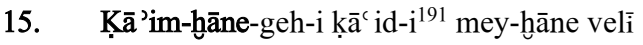

Künc-i mescidde alur uyḳuyı zerrāḳ-1 zamān ${ }^{192}$

16. Çün hezārān nuḳūd-1 dile oldun mālik

Beni gömlek yirine ḩākle ey ḩ̌āce amān

17. Pìzen-i ‘ aḳlı zebūn eyledi siḥr-i nigehị

Rāh-1 zenlikde ise 'anterī geçdi müjgān

18. Sāḳīyā gel ḳapama ḳutnī fem-i mīnāya

Eyleme dīde-i șahbā-keşi gör dü ${ }^{193}$ cihān

19. Hुālden sāde ider ${ }^{194}$ naḳş-1 mușavver ruhuuyı

Bī-nuḳaṭ nāmeyi dahı güzel ${ }^{195}$ oḳur yārān

20. Künc-i çeşmünde ider gamze-i tātārına yer

Niçe mīrzāyı bucag̉a ṣoḳar ol hān-1 zamān

21. Hī̧ burūc çekilür mi mey eyā ḥoḳka dehen

Ne revā' ${ }^{196}$ mā 'il-i ma cūn-1 lebüy ag̉laya ḳan

22. Beyzedürse n'ola jengārı țaraḳlı şāla ${ }^{197}$

Her gören şāne-i meşşātayı zülfünde ' ayān ${ }^{198}$

23. Ablaḳ-1 çarḩa süvār olsa da ḳalbi alaca

Yine menzil alamaz itse ne deplü cevelān

24. İdemez șarf-1 nigeh eşkle çeşm-i bülbül

Şebnem-i çarhlla gülşende gülüy işi ${ }^{199}$ țuman

25. Peşmi ḳoymaz 'acabā derzi bizüm cāmemize

Bādeli $^{200}$ kürdi $^{201}$ girỉbānına döndi dāmān

26. Dilde tașvīr ideli žātını Bihzād-ı hayāl

O tepe-dārı benüm başıma teng oldı cihān

\section{[M1 10a]}

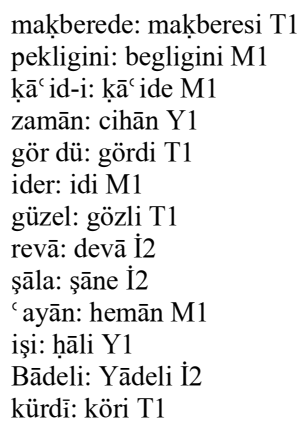


27. Ġarḳ olur ${ }^{202}$ ol mehi āgūşs çeken ten ${ }^{203}$ nūra ${ }^{204}$

Șanma beyhūde ' araḳ-rīz olur ehl-i devrān

$[\mathrm{Y} 1 \mathrm{bb}]$

28. Nîl-i mażmūna cerīm ${ }^{205}$ old $_{1}$ ise tab ${ }^{\complement}-1$ selīm

Hुāme șandāl ana bārīk-i hayāā oldı lebān ${ }^{206}$

29. Ey ṣanem ma' bed-i İslām-1 derāyı neyler

Ne belā idi ${ }^{207}$ bizim başımıza bu efğān

30. Kuş ag̉ı șayd idemez şīr-i ${ }^{208}$ ner-i ser-mesti

Bizi zāhid dilüne țolama eyle iḥsān

[T1 7b]

31. O mehe hāle-i āgūşş-1 kemer-bend yiter

Şāmdan neyler ider 'azm-i reh-i Hindistān

[İ1 6b] [İ2 7a]

32. Nag̉me-i kürdiye çevirir be-ușūl-i evfer ${ }^{209}$

Eylesem eşk-i pür-efşān ${ }^{210}$ ile āheng-i fig̀ān ${ }^{211}$

33. Uçdı ḩațtıla yeleklendi ḩadeng-i hüsni

Ḳāmetüm ḳabża-i cevrinde ${ }^{212}$ dahı̆ şekl-i kemān

34. Nìm-ten ḳaldı meh-i nev gibi çarh-1 gamda

Şimdi ḥasret-keş-i ebrūlaruy ey mihr-i cihān

35. Biniş ${ }^{213}$ eyler ḳavl ile cām eger düzd-i elem ${ }^{214}$

Olsa gāaret-fiken-i şehr-i derūn-1 mestān

36. Eylesen külbe-i aḩzānıma teşrīif eger

Șarılurdım ḳapuda pāyııa ${ }^{215}$ ey serv-i revān

37. Biz bu ser-ḥaddi niçe bekleyelim sulțānım

Kalmadı ḳal' a-i țāḳatde mühimmāt-1 tüvān

38. Ziver-i bār u ber ${ }^{216}$ olayd1 ${ }^{217}$ dıraht-1 ecvef

Kerr ü ferrāca bu vādīde olurdı şāyān

39. Eylese ${ }^{218}$ şemm ile semm mūre eșer ef ${ }^{\mathrm{f}}$ iden

Kākülünden huațt-1 nevhīz bulur mıydı emān

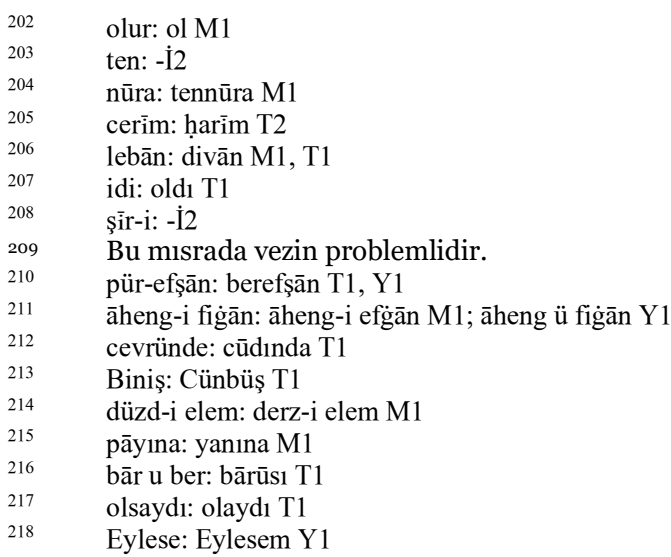




\section{[M1 10b]}

40. Mey-keşin paça ḳafasında ḳomaz derd-i huumār

Düşse ayag̉a n'ola ġam-keş-i lā‘ l-i cānān

41. Zer devā-yı maraż-1 faḳr idigin fehm eyler Yüz ḳızardır kerem erbābına cerrār-ı zamān

42. Lebi zevḳiyle olan eşk-i terin neşvesini Benzedürdük ‘ araḳı bādeye ḳarșāḳ ne ${ }^{219}$ zamān

43. Hande ḳavḳ-1 çemenistān-1 hațādur nāfe Zülf-i pür-çīnüne teşbīh iden eyler 'ișyān

44. Șunasın ${ }^{220}$ cābe ${ }^{221}$ müdāmāne revā $\overline{-2}^{222}$ cāmı bize İtmedi Cem daḩı bu hürrmeti ey pīr-i mugàān

45. Mā 'ilim bir țonı âl ata ele girmez ise Yine sāḳi mey-i gülgūnuya ${ }^{223}$ ḳalur meydān

46. Bāg̀-1 hüsnüy giderek bād-1 hazānīde eser

Sen bu terlikle mi ḳalsạ gerek ey ġonce dehān

\section{[Y1 8a]}

47. İçelüm bādeyi çāḳ şīr-i jiyāna dönelüm

Yaralum Zühre-i șevr-i felegi na' re-zenān

48. Çizme ${ }^{224}$ pergār-ṣıfat ey dil-i pūyān-1 kenār

Vasaṭ-1 dā 'ire-i vefḳ olur ḳuṭba mekān

49. Yüsriyāa çün der-i șanduḳa-i țab` 1 açdum

\section{[T1 8a]}

Alabildigi ḳadar elbise ${ }^{225}$ alsun ${ }^{226}$ yārān

[İ1 7a]

50. İtmedümse n'ola tațīil-i kelāma rag̉bet

Çün ḳubūr yeylisin ister sözin ebnā-yı zamān

51. Bog̣ça bog̣ça tuhaf-1 tesliye ' arż eyleyelim

Şāhid-i sem` -i $^{227}$ veliyyu'n-ni` amīye her ān

[í2 7b] [M1 11a]

52. Ya nī ol müddeșir-i hil' at-i zỉbā-y-şekīb

Rāżi-i ḳısmet-i taḳdīr-i cenāb-ı mennān

53. Köprüli-zāde yegāne güher Es` ad Paşa

Lābis-i çarğab-1 ${ }^{228}$ şāh-1 mülk-i c irfān

ne: -ì2

Șunasın: Șusın İ2

Sunasın cābe: Su sen cābe İ2; Șunasin cām T1

revā: devā M

gülgūnına: gülgūn ile M1

Çizme: Çirme T2

elbise: $-\mathrm{M}$

alsun: +alursa M1

sem`-i: şem $-i \mathrm{Y} 1$

çargab: çar ġayb İ1 


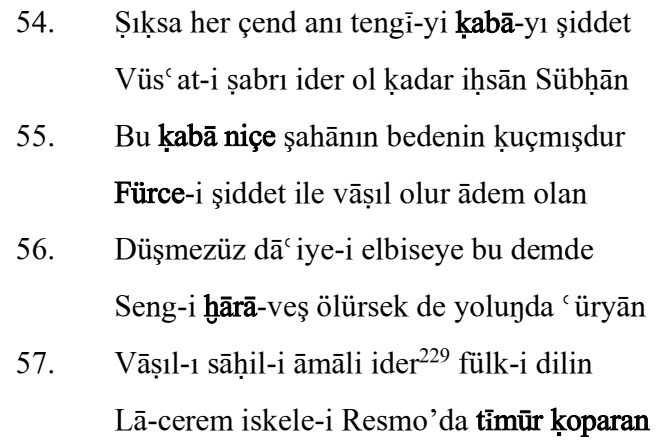

\section{Kaynakça}

Acar, A. (2001). Yüsrî (Hayatı, Eserleri, Edebî Kişiliği ve Dîvânı'nın Tenkitli Metni) (Yayımlanmamış Yüksek Lisans Tezi). Selçuk Üniversitesi Sosyal Bilimler Enstitüsü, Konya.

Ağbal, D. (2012). “Kur'an'da Burçlar Mahiyeti ve İnsana Etkisi Bağlamında”, Atatürk Üniversitesi İlahiyat Fakültesi Dergisi, 38, 241-276.

Argıt, B. (2015). Osmanlı İstanbul'unda Giyim Kuşam. (Ed. A. Bilgin), Antik Çağ’darı 21. Yüzyıla Büyük İstanbul Tarihi, Toplum (c. 4 s. 230-247). İstanbul: İbb Kültür A.Ş.

Atak, M. (2016). Yüsrî Ahmed Nazif Dede ve Dîvânı (İnceleme-Metin). (Yayımlanmamış Yüksek Lisans Tezi). Dokuz Eylül Üniversitesi Sosyal Bilimler Enstitüsü, İzmir.

Bahadır, S. C. (2015). Osmanlı Sosyal Hayatının Divan Şiirine Yansımaları. (Ed. Ö. Şenödeyici), Osmanlı Edebi Metinlerini Anlama Kılavuzu (s. 557-608). İstanbul: Kesit.

Bilgen, S. (1999). Osmanl Dönemi Türk Kadın Giyimi 16. yy-19. yy, (Yayımlanmamış Doktora Tezi). Gazi Üniversitesi Sosyal Bilimler Enstitüsü, Ankara.

Bozkurt, N. (2009). "Sarı", İslam Ansiklopedisi Türkiye Diyanet Vakfı, s. 152-154.

Çetin, H. (1995). Kiyafetli Albüm ve Kitaplardaki Osmanl Kıyafetlerinden Bazı Örnekler. (Yayınlanmamış Yüksek Lisans Tezi). Gazi Üniversitesi Sosyal Bilimler Enstitüsü, Ankara.

Dağll, B. (2007). Kelime Kazanımı Üzerinde Bir Araştırma (Kıyafet ve Kumaş Adları Örneği). (Yayımlanmamış Yüksek Lisans Tezi). Marmara Üniversitesi Eğitim Bilimleri Enstitüsü, İstanbul.

Devellioğlu, F. (2008). Osmanlıca-Türkçe Ansiklopedik Lügat. (Haz. A. S. Güneyçal). Ankara: Aydın

Doğan, M. N. (2011). Eski Şüirin Bahçesinde. İstanbul: Yelkenli.

Erden, A. (1998). Anadolu Giysi Kültürü/Anatolian Garment Culture. Ankara: Dumat.

Ermert, E. (2019). Ansiklopedik Giyim-Kuşam ve Moda Sözlüğü. İstanbul: Hayalperest.

Esin, E. (2004). Orta Asya'dan Osmanliya Türk Sanatinda İkonografik Motifler. İstanbul: Kabalcı.

Goodwin, G. (1997). Osmanlı Kadınının Özel Dünyası. (Çev. S. Gül) İstanbul: Sabah.

Görünür L. ve Ögel S. (2006). “Osmanlı Kaftanları ile Entarilerinin Farkları ve Kullanılışları”, İtü Dergisi Sosyal Bilimler 3 (1), 59-68.

Himam, D. (2013). “16. Yüzyl Giysi Tarihi Yazımı Üzerine: Giysilerde Doğu-Batı Etkileşimi, Egzotizm ve Güç”, Süleyman Demirel Üniversitesi, Fen-Edebiyat Fakültesi Dergisi 29, 91-116.

İpekten, H., İsen, M., Toparlı, R., Okçu, N. ve Karabey T. (1988). Tezkirelere Göre Divan Edebiyatı Ísimler Sözlüğ̈̈u. Ankara: Kültür ve Turizm Bakanlı̆̆ı.

Levend, A. S. (2015). Divan Edebiyat Kelimeler ve Remizler Mazmunlar ve Mefhumlar. İstanbul: Dergâh.

$229 \quad$ ider: olur M1 
Kayaokay, İ. (2018). Divan Şiirinde Elbise Terimleriyle Yazılmış Manzumeler. Ü. Aslan, H. Taş, Ö. Zülfe (ed.), Bir Devr-i Kadim Efendisi Prof. Dr. Tahir Üzgör'e Armă̆an (s. 509-539), Ankara: Yayınevi.

Koçu, R. E. (1969). Türk Giyim Kuşam ve Süslenme Sözlüğü. Ankara: Sümerbank Kültür.

Mecmû'a-i Eşấr, Milli Kütüphane, o6 Mil Yz FB 533/1.

Onay, A. T. (2013). Açıklamah Divan Şiiri Sözlüğü Eski Türk Edebiyatında Mazmunlar ve İzahı. (Haz. C. Kurnaz). Ankara: Berikan.

Özen, M. E. (1981). “Türkçe'de Kumaş Adları”, Tarih Dergisi, İstanbul Üniversitesi Edebiyat Fakültesi Yayınları 33, 291-340.

Özkan, Ö. (2005). Divan Şïrinde Sosyal Hayat (14 ve 15. Yüzyll). (Yayımlanmış Doktora Tezi). Gazi Üniversitesi Sosyal Bilimler Enstitüsü, Ankara.

Öztekin, Ö. (2004). XVIII. Yüzyll Divan Şïrinde Toplumsal Hayatın İzleri: Divanlardan Yansıyan Görüntüler. (Yayımlanmış Doktora Tezi). Hacettepe Üniversitesi Sosyal Bilimler Enstitüsü, Ankara.

Öztoprak, N. (2010). "Divan Şiirinde Giyim Kuşam Üzerine Bir Deneme”, Divan Edebiyat Araştırmaları Dergisi 4, 103-154.

Pakalın, M. Z. (1983). Osmanl Tarih Deyimleri ve Terimleri Sözlüğü I, II, III. İstanbul: Milli Eğitim

Pala, İ. (2009). Ansiklopedik Divan Şïiri Sözlüğü. İstanbul: Kapı

Redhouse, S. J. W. (2006). A Turkish and English Lexicon 3. Edition. İstanbul: Çağrı.

Safâyî, M. (2005). Tezkire-i Safâyî (Nuhbetül-Âsâr min Fevâidi’l-Eş'âr). (Haz. P. Çapan). Ankara: Atatürk Kültür Merkezi Başkanlığı.

Sâlim Efendi. (2005). Tezkiretü’ş-Şu'arâ. (Haz. A. İnce). Ankara: Atatürk Kültür Merkezi Başkanlığı.

Sipahi, B. ve Çetin, A. (2010). "1697-1910 Yılları Arasında Osmanlı Kültüründe Muhasebecilerin Mezar Taşlarının Karakteristik Özellikleri”, Muhasebe ve Finansman Dergisi 48, 232-241.

Sucu, N. (2007). "Zâhid Sûfî Tipinin Kimliği, Divan Edebiyatındaki Yeri ve Sosyal Hayattaki Örnekleri”, İstem 10, 227-253.

Şen, F. M., (2007). "Eski Türk Edebiyatında Sosyal Hayat Çalışmaları", Türkiye Araştırmaları Literatür Dergisi 5 (9), 467-506.

Şeyhi, M. (1989). Şakaik-i Nu’maniye ve Zeyilleri IV. (Haz. A. Özcan). İstanbul: Çağrı.

Tahir, M. (2016). Osmanlı Müellifleri II. (Haz. M. A. Y. Saraç). Ankara: Türkiye Bilimler Akademisi.

Tarama Sözlüğü I, II, III, IV, V, VI (1972). Ankara: Türk Dil Kurumu.

Tezcan, H. (2012). “Modanın Tarihi Dokümanları”, Akdeniz Sanat Hakemli Dergi, 4-7.

Tuman, M. N. (2001). Tuhfe-i Nâilî Divan Şairlerinin Muhtasar Biyografileri II. (Haz. C. Kurnaz, M. Tatçı). Ankara: Bizim Büro.

Türk Dili ve Edebiyatı Ansiklopedisi Devirler/İsimler/Eserler/Terimler VIII. (1998) İstanbul: Dergâh.

Türkiye’de Halk Ağzından Derleme Sözlüğü I, II, III, IV, V, VI (2009). Ankara: Türk Dil Kurumu.

Türkçe Sözlük (2005). Ankara: Türk Dil Kurumu.

Yıldırım, H. (2012). "Divan Şairlerine Göre Burçlar”, Uluslararası Sosyal Araştırmalar Dergisi 8 (41), 340-353.

Yüsrî Ahmed Nazîf Dede Dîvânı, İstanbul Üniversitesi Kütüphanesi, T. 2912

Yüsrî Ahmed Nazîf Dede Dîvânı, İstanbul Üniversitesi Kütüphanesi, T. 2841.

Yüsrî Ahmed Nazîf Dede Dîvânı, Millet Kütüphanesi, Ali Emîrî Efendi Manzum Eserler No. 515. 
Yüsrî Ahmed Nazîf Dede Dîvânı, Milli Kütüphane, o6 Yz A 5357.

Yüsrî Ahmed Nazîf Dede Dîvânı, Topkapı Sarayı Müzesi, Türkçe Yazmaları No. H. 963.

Yüsrî Ahmed Nazîf Dede Dîvânı, Topkapı Sarayı Müzesi, Türkçe Yazmaları No. H. 966.

Yüsrî Ahmed Nazîf Dede Dîvânı, Yapı Kredi Sermet Çifter Araştırma Kütüphanesi, Türkçe Yazmaları No. 688/1

Yüsrî Ahmed Nazîf Dede Dîvânı, Yapı Kredi Sermet Çifter Araştırma Kütüphanesi, Türkçe Yazmaları No. 1016.

\section{İnternet kaynakları}

Aksoyak, İ. (2014). Türk Edebiyatı İsimler Sözlüğü içinde. Erişim adresi:

http://teis.yesevi.edu.tr/madde-detay/yusri-ahmed-yusri-efendi

Kubbealtı Lügati (26.06.2020). Erişim Adresi:

http://lugatim.com/

Kubbealtı Lügati (26.06.2020). "Çeşmibülbül”. Erişim Adresi:

http://lugatim.com/s/\%C3\%87E\%C5\%9EM\%C4\%BoB\%C3\%9CLB\%C3\%9CL

Kubbealtı Lügati (26.06.2020). "Ferecî”. Erişim Adresi:

http://lugatim.com/s/fereci

http://www.yazmalar.gov.tr/ 